\title{
Articles
}

\section{Real convergence in central, eastern and south-eastern Europe}

\author{
Prepared by Piotr Żuk, Eva Katalin Polgar, Li Savelin, Juan Luis Diaz \\ del Hoyo and Paul König
}

This article establishes stylised facts about convergence and analyses the sources of economic growth in central, eastern and south-eastern European (CESEE) economies within and outside the European Union (EU). ${ }^{22}$ It also compares the performance across countries and identifies the challenges that these economies face on the way to further advancing convergence. Although all CESEE economies have converged towards the most advanced EU economies since 2000, progress has been heterogeneous. While some countries have experienced fast economic growth and a speedy catching-up, for others the catching-up process has been rather slow. Economic convergence has been much faster in the CESEE countries that became members of the EU (including those which later joined the euro area) than in the Western Balkan countries that are currently EU candidates or potential candidates. Convergence was particularly rapid before the global financial crisis, but slowed down thereafter.

The article identifies several factors that are common to the most successful countries in the region in terms of the pace of convergence since 2000. These include (inter alia) improvements in institutional quality, external competitiveness and innovation, increases in trade openness, high or improving levels of human capital, and relatively high investment rates. Looking ahead, accelerating and sustaining convergence in the region will require further efforts to enhance institutional quality and innovation, reinvigorate investment, and address the adverse impact of population ageing. For EU candidates and potential candidates, EU accession prospects might constitute an anchor for reform momentum - in particular, but not exclusively, in the key area of enhancing institutional quality - and thus support the long-term growth prospects and real convergence of these countries.

22 This article focuses on the CESEE countries which are EU members (referred to as "new EU Member States" (NMS) and comprising Bulgaria, the Czech Republic, Estonia, Croatia, Latvia, Lithuania, Hungary, Poland, Romania, Slovenia and Slovakia) or which are EU candidates or potential candidates (referred to as the "Western Balkans" and comprising Albania, Bosnia and Herzegovina, the former Yugoslav Republic of Macedonia, Montenegro and Serbia). Kosovo is also included in the analysis wherever data are available (without prejudice to positions on status, in line with the United Nations Security Council Resolution 1244 and the International Court of Justice's opinion on Kosovo's declaration of independence). Although Turkey is an EU candidate country, it is not included in the analysis, since it does not share the background of an economic transition from a command economy to a market economy. 
CESEE economies embarked on a major economic transition from command economies to market economies in the 1990s. This economic transition has largely shaped economic developments in these countries since 1990. Despite high transitional costs and overall mixed economic performance in the 1990s, most CESEE economies have experienced high economic growth since 2000, which has contributed to a catching-up towards the most advanced economies in the EU.

This article analyses the income convergence of CESEE economies towards the most advanced EU economies since $2000 .^{23}$ The analysis includes: (i) the eleven economies that joined the EU in this period, five of which have since also adopted the euro; and (ii) the six economies from the Western Balkans that are EU candidates or potential candidates. Real convergence - understood as a process in which economic growth in poorer countries is faster than that in richer ones, and so real income differences between the countries diminish over time - has far-reaching implications for economic welfare and well-being. Furthermore, the attainment of sustainable convergence remains important for economic and monetary integration with, and within, the EU. This stems from the fact that achieving sustainable convergence narrows real income disparities, supports social cohesion and thus facilitates the functioning of Economic and Monetary Union.

Furthermore, there is a close link between convergence in real incomes and convergence in prices (nominal convergence). Faster-growing (converging) economies usually experience real exchange rate appreciation, which often materialises through higher inflation rates. After entering Monetary Union, however, higher inflation may lead to lower real interest rates than in other Monetary Union member countries. Along with the typically higher natural interest rates, the likelihood of the faster-growing economies experiencing boom-bust cycles rises, unless fiscal or macroprudential policy instruments are properly applied in such economies to preserve macro-financial stability. By the same token, real income convergence facilitates abiding by the Maastricht convergence criteria for Monetary Union membership (including the inflation and long-term interest rate criteria), which remains relevant for EU Member States that are not yet using the euro. ${ }^{24}$

The lack of income convergence is often coupled with a low degree of institutional quality, i.e. the institutional and governance standards that facilitate the economic growth of a country and make it more resilient to shocks. This may

23 Convergence should be analysed over a long time horizon. However, due to the economic transition which CESEE countries underwent in the 1990s and data limitations in some countries, 2000 appears to be the natural starting point for conducting such an analysis for this group of countries.

24 A more detailed analysis of the relationship between real convergence and nominal convergence (which, together with fiscal convergence, are often referred to as "Maastricht convergence") can be found in Diaz del Hoyo, J.L., Dorrucci, E., Ferdinand Heinz, F. and Muzikarova, S., "Real convergence in the euro area: a long-term perspective", Occasional Paper Series, No 203, ECB, December 2017. 
complicate the further integration and smooth functioning of the EU and of the euro area. $^{25}$

Against this background, Section 2 reviews stylised facts about convergence in CESEE countries, Section 3 analyses the drivers of economic convergence in this group of countries and Section 4 concludes.

\section{Box 1}

Background information on CESEE countries

Prepared by Piotr Żuk, Eva Katalin Polgar, Li Savelin, Juan Luis Diaz del Hoyo and Paul König

The CESEE economies have several characteristics in common. First, they share a joint legacy of being command economies that embarked on a transition process to market economies in the 1990s. Second, all of them are small open economies with a close proximity to and strong economic ties with larger EU economies. Third, all of them have either joined the EU already or are EU candidates or potential candidates with the prospect of joining the EU at some point in the future. The table presents basic country information for all of the economies analysed in this article. Overall, the country sample includes 17 CESEE countries, comprising eleven new EU Member States (NMS) - which include six non-euro area EU Member States (referred to in the charts as non-euro area NMS) and five euro area NMS - and six EU candidates and potential candidates, which in this article are collectively referred to as the Western Balkans.

25 See also Cœuré, B., "Convergence matters for monetary policy", speech given at the conference "Innovation, firm size, productivity and imbalances in the age of de-globalization", Brussels, 30 June 2017. 
Table A

EU membership status, population and income levels

\begin{tabular}{|c|c|c|c|c|}
\hline Country & Official status & $\begin{array}{c}\text { Population } \\
\text { (2016, millions) }\end{array}$ & $\begin{array}{c}\text { Real GDP per capita } \\
\text { (2016, PPP, international } \\
\text { USD) }\end{array}$ & $\begin{array}{l}\text { Real GDP per capita } \\
\text { (2016, as a percentage } \\
\text { of the EU28 average) }\end{array}$ \\
\hline \multicolumn{5}{|l|}{ Euro area NMS } \\
\hline Slovenia & $\begin{array}{l}\text { Member since 2004; } \\
\text { using the euro since } 2007\end{array}$ & 2.1 & 29,933 & 82.4 \\
\hline Slovakia & $\begin{array}{l}\text { Member since 2004; } \\
\text { using the euro since } 2009\end{array}$ & 5.4 & 29,224 & 80.4 \\
\hline Estonia & $\begin{array}{l}\text { Member since 2004; } \\
\text { using the euro since } 2011\end{array}$ & 1.3 & 28,095 & 77.3 \\
\hline Latvia & $\begin{array}{c}\text { Member since 2004; } \\
\text { using the euro since } 2014\end{array}$ & 2.0 & 23,718 & 65.3 \\
\hline Lithuania & $\begin{array}{c}\text { Member since 2004; } \\
\text { using the euro since } 2015\end{array}$ & 2.9 & 27,904 & 76.8 \\
\hline \multicolumn{5}{|l|}{ Non-euro area NMS } \\
\hline Czech Republic & Member since 2004 & 10.6 & 31,353 & 86.3 \\
\hline Hungary & Member since 2004 & 9.8 & 25,654 & 70.6 \\
\hline Poland & Member since 2004 & 38.4 & 26,051 & 71.7 \\
\hline Bulgaria & Member since 2007 & 7.1 & 17,794 & 49.0 \\
\hline Romania & Member since 2007 & 19.7 & 21,608 & 59.5 \\
\hline Croatia & Member since 2013 & 4.2 & 21,547 & 59.3 \\
\hline \multicolumn{5}{|l|}{ Western Balkans } \\
\hline Albania & $\begin{array}{c}\text { Candidate since June } 2014 \text { (accession } \\
\text { negotiations have not yet been } \\
\text { opened) }\end{array}$ & 2.9 & 11,359 & 31.3 \\
\hline FYR Macedonia & $\begin{array}{l}\text { Candidate since December } 2005 \\
\text { (accession negotiations have not yet } \\
\text { been opened) }\end{array}$ & 2.1 & 13,055 & 35.9 \\
\hline Montenegro & $\begin{array}{l}\text { Candidate since December } 2010 \\
\text { (negotiations opened in June 2012) }\end{array}$ & 0.6 & 15,725 & 43.3 \\
\hline Serbia & $\begin{array}{l}\text { Candidate since March } 2012 \\
\text { (negotiations opened in January 2014) }\end{array}$ & 7.1 & 13,723 & 37.8 \\
\hline Bosnia and Herzegovina & $\begin{array}{l}\text { Potential candidate (applied for EU } \\
\text { membership in February 2016) }\end{array}$ & 3.5 & 11,327 & 31.2 \\
\hline Kosovo & $\begin{array}{l}\text { Potential candidate (has not applied for } \\
\text { EU membership) }\end{array}$ & 1.8 & 9,332 & 25.7 \\
\hline
\end{tabular}

Sources: European Commission, Haver Analytics, World Bank and ECB calculations.

\section{Convergence in CESEE economies: stylised facts}

In all CESEE economies, real GDP per capita in $\mathrm{PPP}^{26}$ measured as a share of the EU28 average has increased since 2000 (see Chart 1). GDP per capita growth was particularly strong in the run-up to the 2008-09 global financial crisis, reaching close to, or exceeding, $5 \%$ in some new EU Member States and in the

26 Using purchasing power parity (PPP) eliminates the effect of price level differences between countries and thus allows a more accurate measurement of welfare that can be compared across countries. 
poorest Western Balkan economies. The strong economic expansion contributed to a faster catching-up with the higher-income EU economies. However, since 2009 economic growth has slowed in all countries in the region. As a result, the convergence towards the EU28 average has decelerated, although some countries, such as the Baltic countries and Poland, managed to catch up at a relatively fast pace again after 2010.

\section{Chart 1}

Real GDP per capita in PPP in 2000, 2008 and 2016

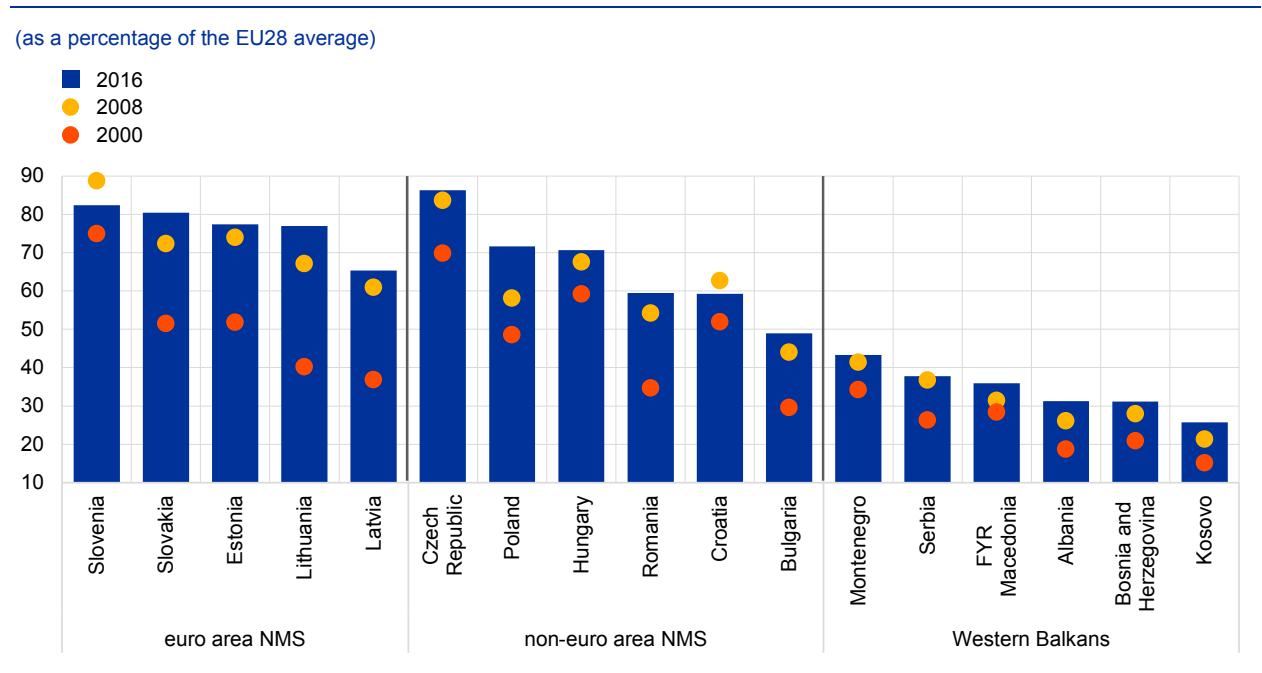

Sources: World Bank (World Development Indicators - WDI) and ECB calculations.

The catching-up process in CESEE countries that are EU Member States has been generally faster than in the Western Balkans. This is partly due to the destructive impact of the Yugoslav wars in the 1990s, which delayed the economic transition process in many Western Balkan economies by nearly a decade.

Developments have also been heterogeneous across CESEE countries that are EU Member States. Some of them - in particular the Baltic countries and Slovakia, which have joined the euro area, as well as Bulgaria, Poland and Romania - have experienced particularly fast convergence. At the same time, other CESEE EU Member States have found it difficult to converge to the EU average beyond the levels already achieved by 2008. In fact, GDP per capita in Croatia and Slovenia diverged from the EU average after 2008, although this negative trend has been reversed in more recent years.

Some new EU Member States, such as the Czech Republic, Slovenia and Slovakia, have by now reached GDP per capita levels somewhat above $80 \%$ of the EU average (based on 2016 data). By contrast, some other new EU Member States still remain well below the EU average. This is the case, in particular, for Bulgaria (with the lowest GDP per capita level of these countries, at close to $50 \%$ ), Romania and Croatia (both at around 60\%).

In turn, in 2016 all Western Balkan economies had income levels amounting to less than $50 \%$ of the EU28 average. The lowest GDP per capita in PPP terms was measured in Kosovo (26\%) and the highest in Montenegro (43\%). Overall, most Western Balkan economies are still far from achieving the level of income 
convergence towards the EU average that was typical at the time of EU accession for other CESEE countries (which in most cases amounted to around $50-60 \%$ of the average GDP per capita in the EU). ${ }^{27}$

Assuming the continuation of the GDP growth trends observed in recent years, many new EU Member States will converge relatively quickly (some as soon as in the next decade) to the EU28 average in terms of GDP per capita. At the same time, for many other new Member States, convergence to the EU28 average before 2030 does not appear to be achievable without a marked acceleration in GDP growth going forward. ${ }^{28}$ As can also be seen in Chart 2 , which depicts the results of a similar mechanical computation for the Western Balkans, all of these economies (except Montenegro) would need to exhibit much higher GDP growth rates than recorded in previous years in order to reach $50 \%$ of the average GDP per capita of the EU28 by 2030 .

\section{Chart 2}

Growth required in GDP per capita in the Western Balkan countries to achieve $50 \%$ of the EU28 average by 2025, 2030 and 2035

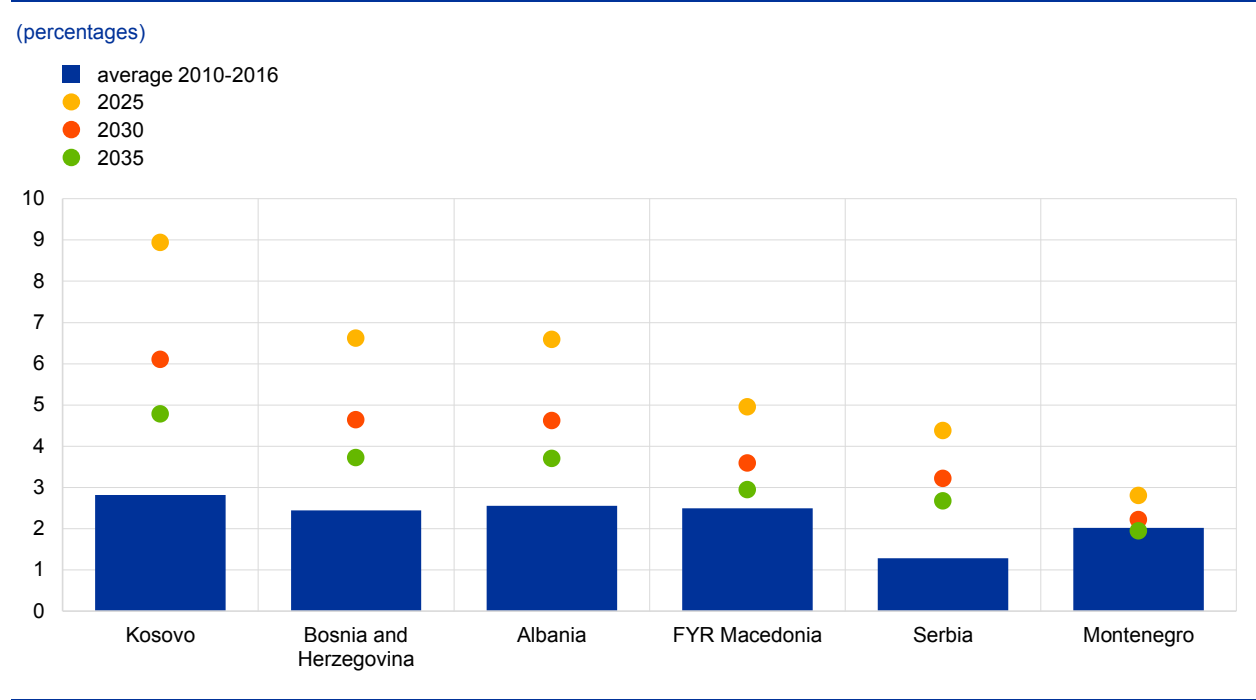

Sources: World Bank (WDI) and ECB calculations.

Note: Assuming average annual GDP growth in the EU28 (per capita, in PPP) of 1.2\%, i.e. the rate observed in the period 2010-16.

Overall, there has been a negative correlation between income levels in $\mathbf{2 0 0 0}$ and real GDP growth in subsequent years (see Chart 3). This indicates that as a general trend poorer CESEE countries have experienced stronger economic growth since 2000. In this context, two observations appear particularly striking. First, a stronger convergence process appears to have occurred in the new EU Member States that joined the euro area than in the other two groups of countries. Second, an analysis of the Western Balkan countries and the non-euro area new EU Member

27 Among the CESEE countries that have joined the EU since 2004, the lowest GDP per capita (as a percentage of the EU28 average) at the time of accession was observed in Bulgaria (42.3\%) in 2007. In addition, some other countries had levels of around $50 \%$, e.g. Latvia (48.3\%) and Poland (51.2\%) in 2004, and Romania (49.4\%) in 2007

28 These mechanical calculations assume that GDP growth in the EU and CESEE countries remained at the average level from 2010 to 2016 . These calculations do not take into account the impact of the United Kingdom leaving the EU, which will reduce in statistical terms the EU average income level. 
States with similar income levels in 2000 reveals that the latter group has experienced a much higher average annual growth rate. These two observations might point to the positive role that EU accession has played in the convergence of CESEE economies.

\section{Chart 3}

Initial income levels and average GDP growth between 2000 and 2016

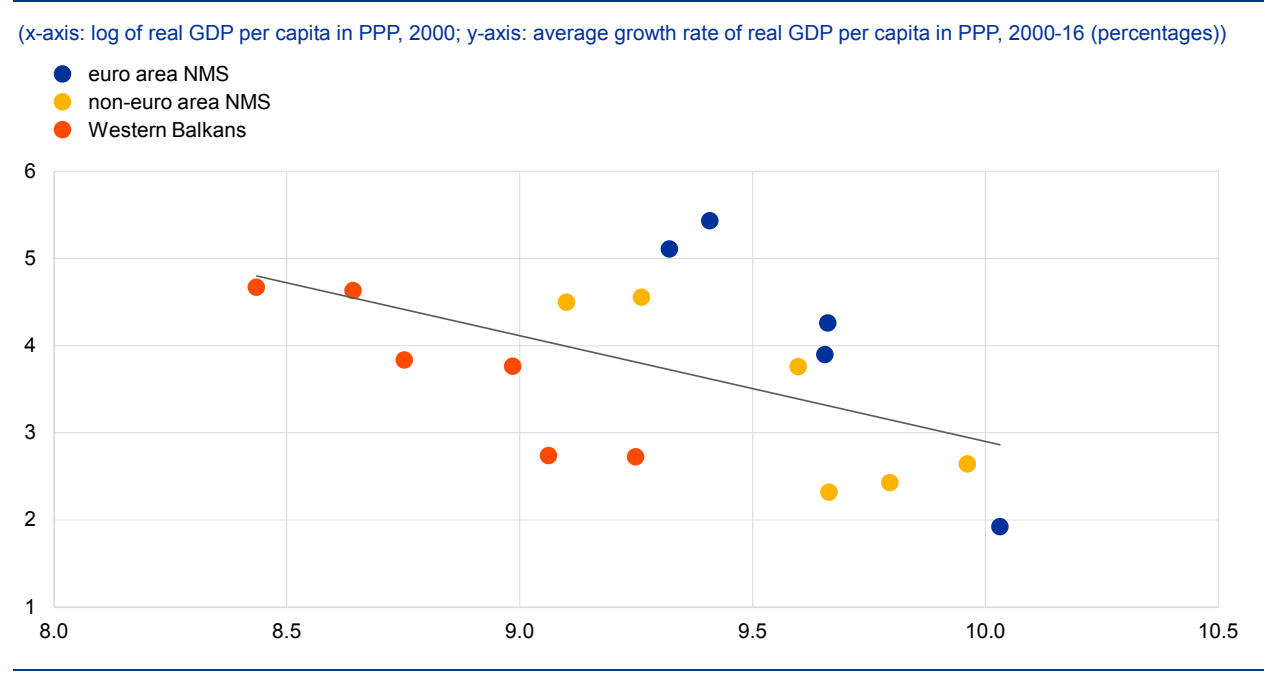

Sources: World Bank (WDI) and ECB calculations.

Income dispersion within the group of new EU Member States and the group of Western Balkan economies has narrowed since $2000 .{ }^{29}$ At the same time, the real incomes of these two groups of countries have diverged (see Chart 4). These developments support the "club convergence" hypothesis and suggest that new EU Member States and prospective EU Member States may have been converging to different steady states.

29 As measured by the standard deviation of real GDP per capita in PPP as a share of the EU average. 


\section{Chart 4}

Income dispersion vis-à-vis the EU28 in the period 2000-16

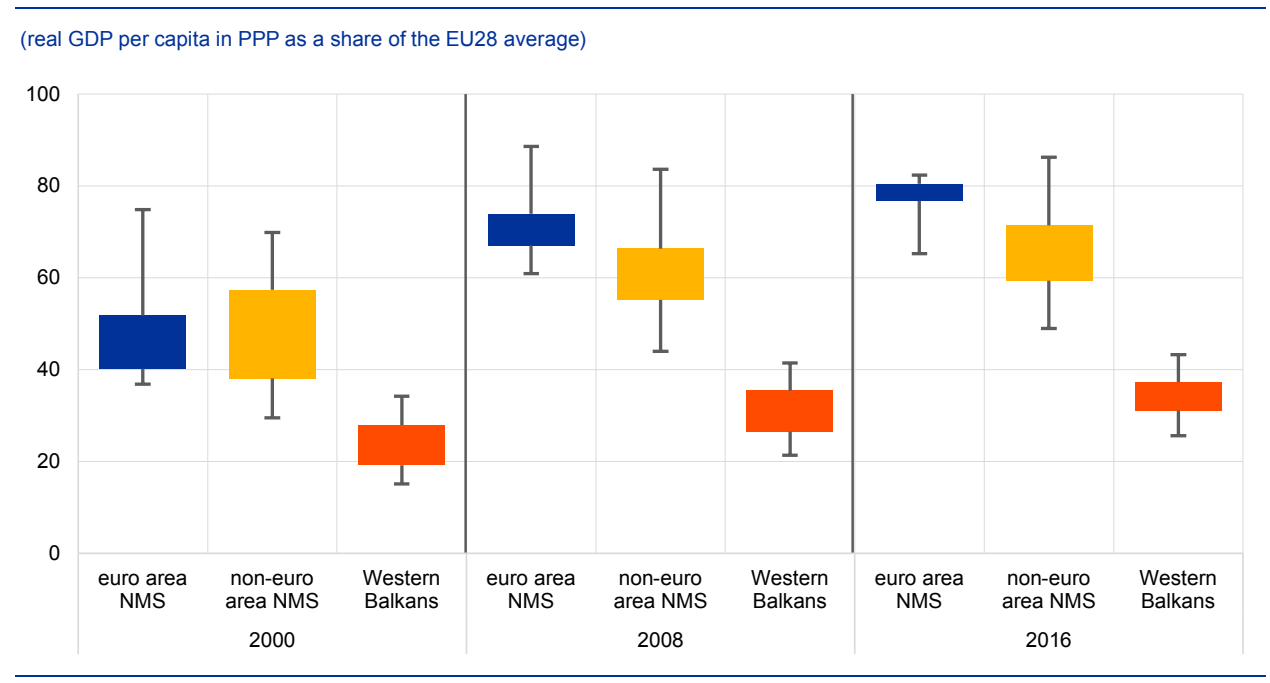

Sources: World Bank (WDI) and ECB calculations.

Notes: The upper whisker denotes the maximum value in the sample and the lower whisker, the minimum value. The boxes indicate the dispersion between the first and the third quartiles.

\section{Box 2}

Theories of convergence and economic growth

Prepared by Piotr Żuk, Eva Katalin Polgar, Li Savelin, Juan Luis Diaz del Hoyo and Paul König

Several different concepts of economic convergence have been developed in the literature, but the so-called " $\beta$-convergence" and " $\sigma$-convergence" are the most frequently used. $\beta$-convergence implies that lower-income countries tend to grow faster than higher-income ones and is a necessary, but not sufficient, condition for $\sigma$-convergence, which entails that the dispersion in real incomes among countries tends to diminish over time. Thus, if $\beta$-convergence holds, poorer countries grow faster than richer ones, but higher growth rates may not be sufficient to equalise income levels across countries over time due to high initial income differences between them, so $\sigma$ convergence does not necessarily follow. The concept of $\beta$-convergence derives from the neoclassical growth framework and is based on the assumption of diminishing returns to capital. ${ }^{30}$ In this framework, capital-scarce (low-income) economies exhibit higher returns on this factor of production than capital-abundant (high-income) ones, which promotes faster capital accumulation and economic growth in the former group of economies.

The concept of the conditionality of convergence is also often discussed in the literature. Conditional convergence takes into account that institutional settings or policies may differ across countries. Thus, economies may converge towards different steady states and economic growth in poorer economies may not automatically be higher than that in richer ones; whereas unconditional (absolute) convergence suggests that poorer countries grow faster than richer ones irrespective of the institutional settings or policies pursued. ${ }^{31}$ Empirical evidence, however, does not find

30 Solow, R., "A contribution to the theory of economic growth", Quarterly Journal of Economics, Vol. 70(1), 1956, pp. 65-94, and Swan, T.W., "Economic Growth and Capital Accumulation", Economic Record, Vol. 32(2), 1956, pp. 334-361.

31 Barro, R.J. and Sala-i-Martín, X.I., Economic Growth, 2nd Edition, MIT Press, Cambridge (Mass.), 2004. 
conclusive evidence of unconditional convergence for large country sets. In the words of Rodrik ${ }^{32}$, "Whatever convergence one can find is conditional: it depends on policies, institutions, and other country-specific circumstances" such as the saving rate, demographics or foreign aid. One implication of conditional convergence is that economies with similar characteristics (such as OECD or CESEE economies) are likely to converge to the same steady state in the longer term, and that would differ from the steady state of other groups of countries that share different characteristics. This concept is often described as "club convergence".

If - as the conditional convergence concept implies - convergence is not a quasi-automatic process, then determining the drivers of economic growth and conditions that are supportive of growth would appear to be crucial from a policy perspective. While the growth models of Solow and Swan focused on capital accumulation as the main driver of growth (and treated technological progress as exogenous), the next wave of the theoretical literature strived to endogenise technological change by using models which included the accumulation of human capital, innovation, investment in research and development or learning by doing. ${ }^{33}$ However, endogenous growth models have also been criticised for not explaining the fundamental determinants of growth. For example, cross-country differences in innovation or human capital accumulation may explain differences in income levels, but they do not answer the question of why the countries pursue different policies in these areas.

Therefore, in the 1990s the literature started to focus on institutions as the fundamental explanation of growth, of income differences across countries, and of convergence. Institutions are understood as "the rules of the game in a society", which shape incentives of economic actors in terms of investing in physical and human capital or developing new technologies. ${ }^{34}$ The term "institutions" may include a wide variety of "rules of the game", both formal and informal, such as property rights, contract enforcement, the effectiveness of the judicial system, the control of corruption, and the quality of regulation and governance, conflict management or political stability. ${ }^{35}$

Developed more recently, and linked to the focus on the role of sound institutions, is the new concept of sustainable economic convergence; this is the process whereby the income per capita levels of lower-income economies catch up, on a durable basis, with those of higher income economies. For real convergence to be sustainable, the expansion of aggregate demand must be consistent with long-term potential output growth. Higher growth that results, for instance, from a financial boom may prove to be unsustainable if not matched by higher potential growth. To be sustainable, real convergence should be underpinned by sound policies and institutions. In this

32 Rodrik, D., "Unconditional convergence", National Bureau of Economic Research (NBER) Working Paper No 17546, 2011.

33 See for example: Romer, P.M., "Increasing Returns and Long-Run Growth", Journal of Political Economy, Vol. 94(5), 1986, pp. 1002-1037; Romer, P.M., "Growth Based on Increasing Returns Due to Specialization", American Economic Review, Vol. 77(2), 1987, pp. 56-62; Romer, P.M., "Endogenous Technological Change", Journal of Political Economy, Vol. 98(5), 1990, pp. 71-102; Aghion, P. and Howitt, P., "A Model of Growth Through Creative Destruction", Econometrica, Vol. 60(2), 1992, pp. 323-351; and Lucas, R.E., "On the Mechanics of Economic Development", Journal of Monetary Economics, Vol. 22(1), 1988, pp. 3-42.

34 North, D., Institutions, Institutional Change and Economic Performance, Cambridge University Press, 1990; Acemoglu, D., Johnson, S. and Robinson, J., "Institutions as a Fundamental Cause of Long-Run Growth", in Aghion, P. and Durlauf, S. (eds.), Handbook of Economic Growth, North Holland, Amsterdam, 2005, pp. 385-472.

35 Rodrik, D., "Institutions for High-Quality Growth: What They are and How to Acquire Them", NBER Working Paper No 7540, 2000 
respect, it has been shown recently that institutional quality is an important explanatory variable for cross-country growth differentials across the EU and for long-term growth in European economies. ${ }^{36}$

Another prominent concept in the literature focuses on geographical advantages and agglomeration effects. According to these concepts, geographical location may create advantageous conditions for growth and productivity due to possible complementarities and spillovers between firms in clusters, which might result in economies of scale in production and attract new companies. At the same time, geographical location influences transportation costs, while climate might affect productivity directly (e.g. in agriculture) or indirectly through the health and human capital of the population. One important implication is that the agglomeration effects may be self-reinforcing, which could explain the persistency of the dispersion of income levels across regions. ${ }^{37}$ The agglomeration effects also help to explain why some geographical areas have been more economically successful than others, despite similar characteristics in terms of institutional quality, for example.

\section{Drivers of economic convergence in CESEE countries}

This section is structured as follows: Section 3.1 presents the results of a growth accounting exercise for CESEE economies; Sections 3.2 and 3.3 analyse, respectively, both capital and labour accumulation as drivers of economic growth; and Section 3.4 reviews factors which may have had a particular impact on total factor productivity (TFP) growth in CESEE countries.

\subsection{Growth accounting}

Growth accounting allows for a quantification of the contributions of capital and labour accumulation, and TFP growth, to total economic growth. Under this approach, output is assumed to be a function of the inputs used in the production process (capital and labour) and total factor productivity ${ }^{38}$. The capital stock and labour supply (and their respective shares in GDP) can in principle be measured, as can their contributions to GDP growth. However, TFP and its contribution to growth are usually assumed to be equal to the part of economic growth that cannot be explained by the accumulation of those two factors of production.

According to this approach, economic growth in CESEE countries since 2000 has been based mostly on rising total factor productivity (see Chart 5). This can be largely attributed to reforms fostering the transition from a command

36 See for instance Masuch, K., Moshammer, E. and Pierluigi, B., "Institutions and growth in Europe", CEPS Working Document No 421, 2016

37 See, among others: Krugman, P., "Increasing returns and economic geography", Journal of Political Economy, Vol. 99, 1991, pp. 483-499; Fujita, M., Krugman, P. and Venables, A.J., The Spatial Economy: Cities, Regions, and International Trade, MIT Press, 1999; Gallup, J.L., Sachs, J.D. and Mellinger, A.D., "Geography and economic development", International Regional Science Review, Vol. 22, 1999, pp. 179-232.

38 According to its more general definition, total factor productivity is the portion of output that is not explained by the amount of inputs used in production. Thus, it is calculated as a residual and its level is determined by how efficiently and intensively the inputs are used in the production process. 
economy to a market economy, which supported a more efficient use of factors of production. Capital accumulation also contributed positively to growth. By contrast, these countries have experienced mixed demographic developments and, as a result, the labour contribution to growth has been, on average, close to zero. This growth pattern is somewhat different from that of many other converging emerging market economies often analysed in the literature, where growth has mostly been based on both capital and labour accumulation. ${ }^{39}$

\section{Chart 5}

Contributions to economic growth from labour, capital and total factor productivity (TFP) in the periods $2000-08$ and $2010-14$

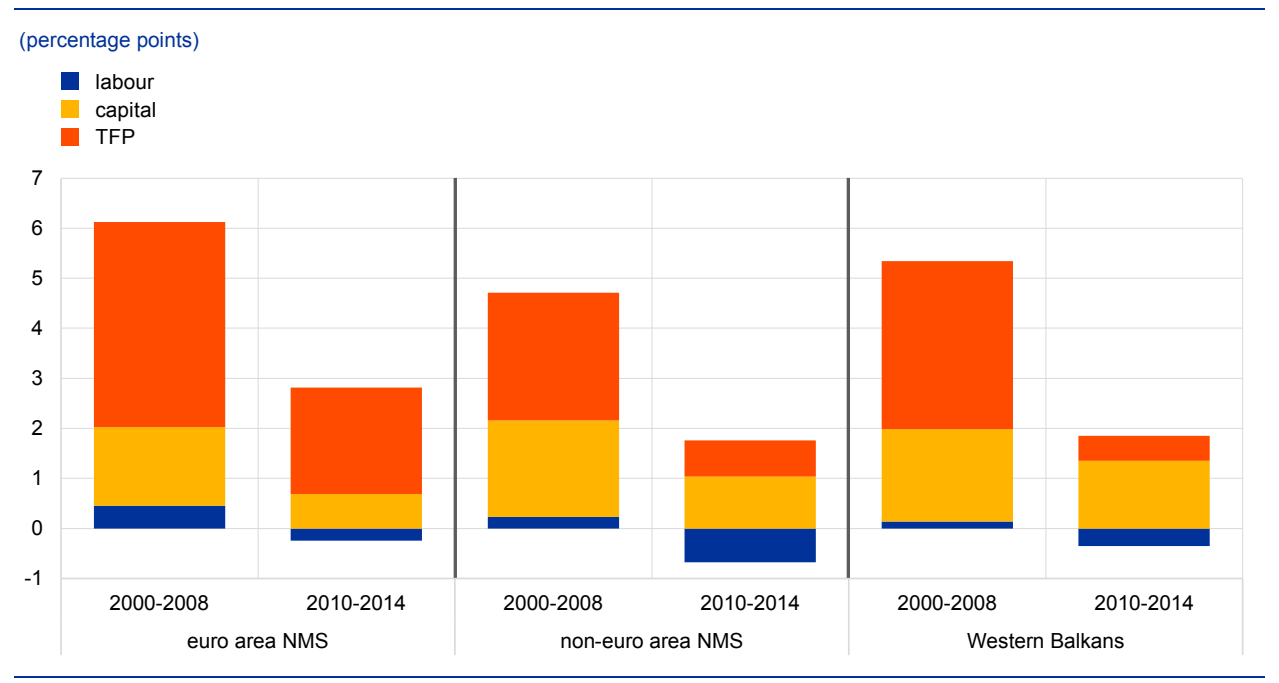

Sources: Penn World Table version 9.0 and ECB calculations.

Notes: The labour share in Albania and Montenegro is assumed to be equal to the average of FYR Macedonia, Bosnia and Herzegovina, Serbia and Croatia. Average hours worked in the Western Balkan countries are assumed to be equal to the average worked in the new Member States. The calculations assume a standard Cobb-Douglas production function. Data are available only up to 2014 .

Nevertheless, the relative strength of the drivers of economic growth in the CESEE region has been heterogeneous both across countries and periods of time. Before the crisis (i.e. between 2000 and 2008), the relative strength of the main drivers of growth was broadly similar throughout the region, with a particularly strong contribution from TFP growth and capital accumulation. While labour accumulation on average also supported economic growth, its contribution remained small in all groups of economies.

The post-crisis economic slowdown was mostly associated with slower TFP growth. As a result, economic growth in the region became more reliant on capital accumulation. This was particularly visible in the Western Balkans, where capital accumulation became, in practice, the only driver of economic growth. In the new EU Member States outside the euro area, the contribution from capital accumulation also became the main driver of growth; however, TFP growth also explained a significant part of total economic growth. By contrast, in the euro area countries of the region, TFP growth remained the main driver of growth. At the same time,

39 See, for example, Transition Report 2017-18, European Bank for Reconstruction and Development (EBRD), 2017 
headwinds from a shrinking labour force became a drag on growth in all three groups of countries.

\subsection{The capital stock and its accumulation}

The capital stock per person employed remains substantially below the EU28 average in almost all CESEE economies (see Chart 6). The gaps to more advanced EU economies are particularly large in south-eastern Europe, where in some countries the capital stock amounts to only around one-third of the EU28 average. Low capital stocks are also mirrored in the poor quality of infrastructure, in particular in prospective EU member countries. ${ }^{40}$

\section{Chart 6}

Capital stock per person employed and labour productivity in CESEE countries in 2014

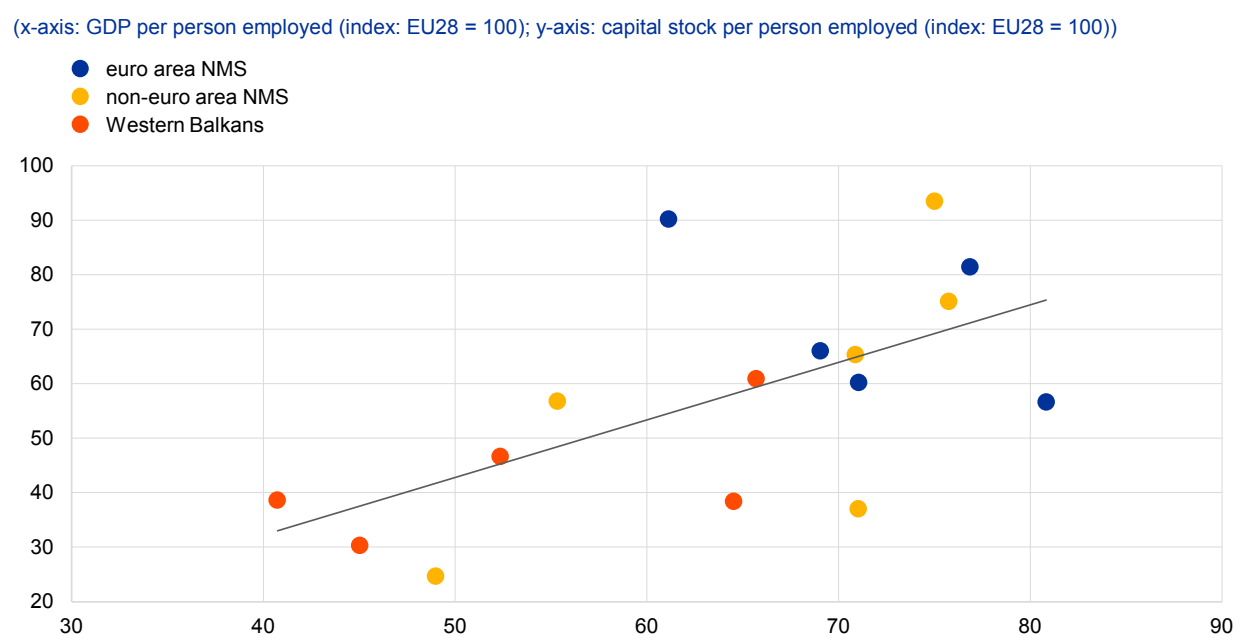

Sources: Penn World Table version 9.0 and IMF (World Economic Outlook).
Notes: The blue dots depict new Member States which have adopted the euro, the yellow dots new Member States not part of the euro Notes: The blue dots depict new Member States which have adopted the euro, the yellow
area and the red dots the Western Balkan economies. Data are available only up to 2014.

Against this background, high investment rates appear essential for convergence towards the higher-income EU economies. While investment was booming in most CESEE economies before 2008, domestic saving rates were not sufficient to finance investment expenditures. Thus, large saving gaps (i.e. the differences between domestic saving and investment rates relative to GDP) constituted a common characteristic of CESEE countries. These gaps were particularly large in south-eastern Europe, including in those economies that are currently EU candidates and potential candidates, and in the Baltic countries, where in some cases saving gaps exceeded 10 percentage points (see Chart 7 ).

40 See, for example, the World Bank Logistics Performance Index. 


\section{Chart 7}

Average saving and investment rates in the periods 2000-08 and 2010-16

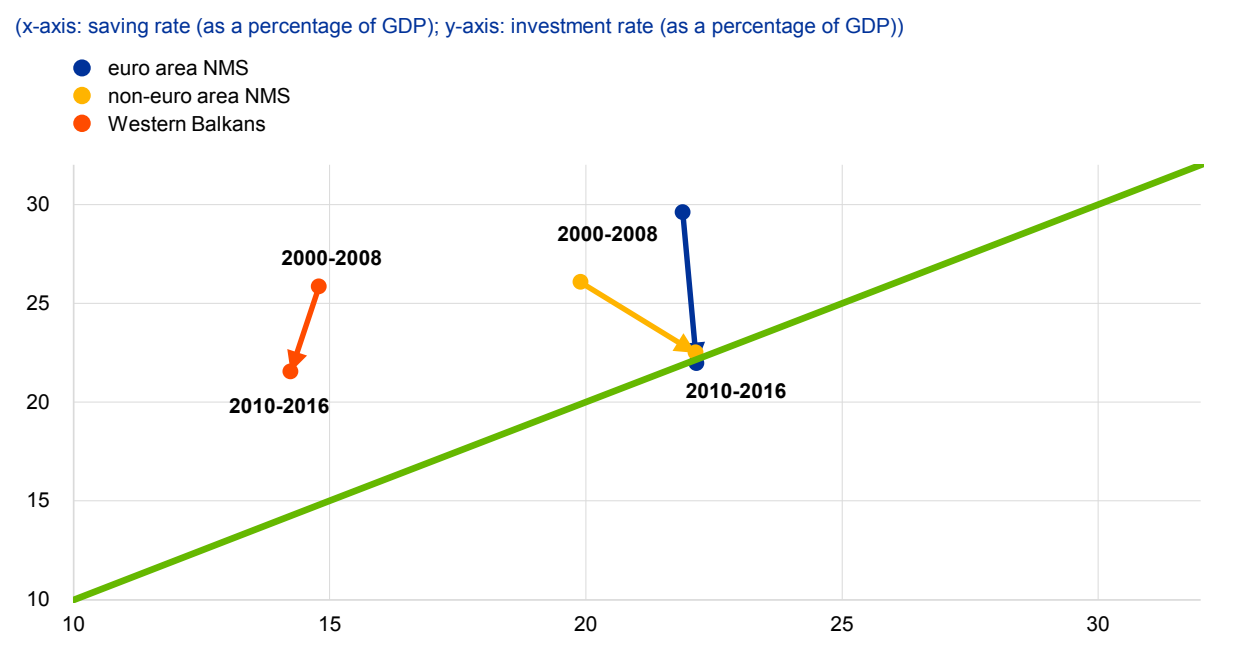

Sources: IMF (World Economic Outlook) and ECB calculations. Note: The 45-degree line is shown in green.

In an environment of limited domestic savings, the investment boom prior to the crisis was financed largely with capital inflows. These capital inflows included, in particular, bank loans and foreign direct investment (FDI) (see Chart 8). ${ }^{41}$ High investment rates contributed to rapid capital accumulation and FDI also enabled technology and know-how transfer, thereby supporting TFP growth. Often the investment boom also reflected strong activity in the construction sector, driven by housing booms in many CESEE countries before the crisis; however these had a more limited impact on labour productivity and long-term growth prospects (see Chart 9). ${ }^{42}$

41 Bakker, B and Gulde, A.-M., "The Credit Boom in the EU New Member States: Bad Luck or Bad Policies?", International Monetary Fund (IMF) Working Paper No 10/130, 2010.

42 See, for example, Sala-i Martin, X., "I Just Ran Four Million Regressions", American Economic Review, Vol. 87(2), 1997, pp. 178-183. The author found that non-equipment investment has no impact on GDP growth, if the level of total investment is controlled for. At the same time, the paper confirmed a strong link between equipment investment and growth. 


\section{Chart 8}

Average foreign direct investment (FDI) inflows in the periods 2000-08 and 2010-16

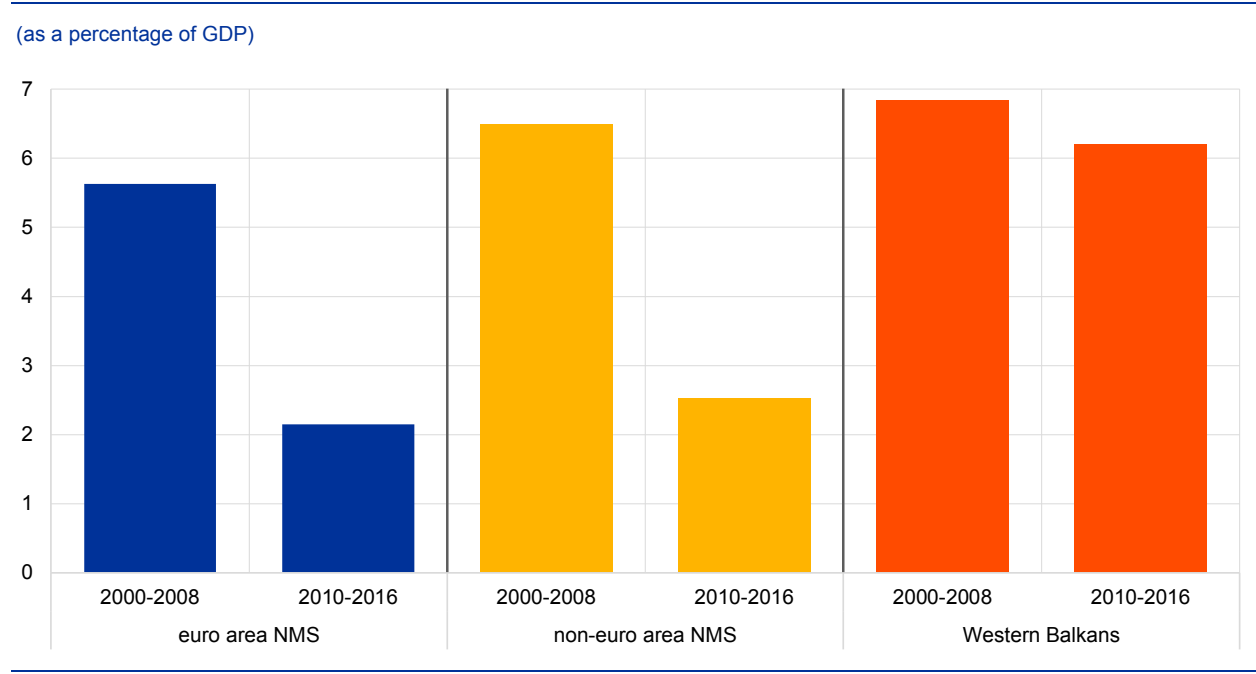

Sources: Vienna Institute for International Economic Studies (wiiw) (FDI database) and ECB calculations. Note: Data in gross terms.

After the crisis, investment rates declined substantially. This took place against the backdrop of slower GDP growth, lower capital inflows, a slowdown in construction activity and lower credit growth amid private sector deleveraging following a build-up of debt before the crisis. As a result, only a few CESEE economies managed to maintain investment rates above $25 \%$ of GDP. This happened despite a larger inflow of EU structural and cohesion funds, which in the new EU Member States have risen to around 1.0-1.5\% of GDP since around $2008 .{ }^{43}$

\section{Chart 9}

Average total construction value added in the period 2000-16

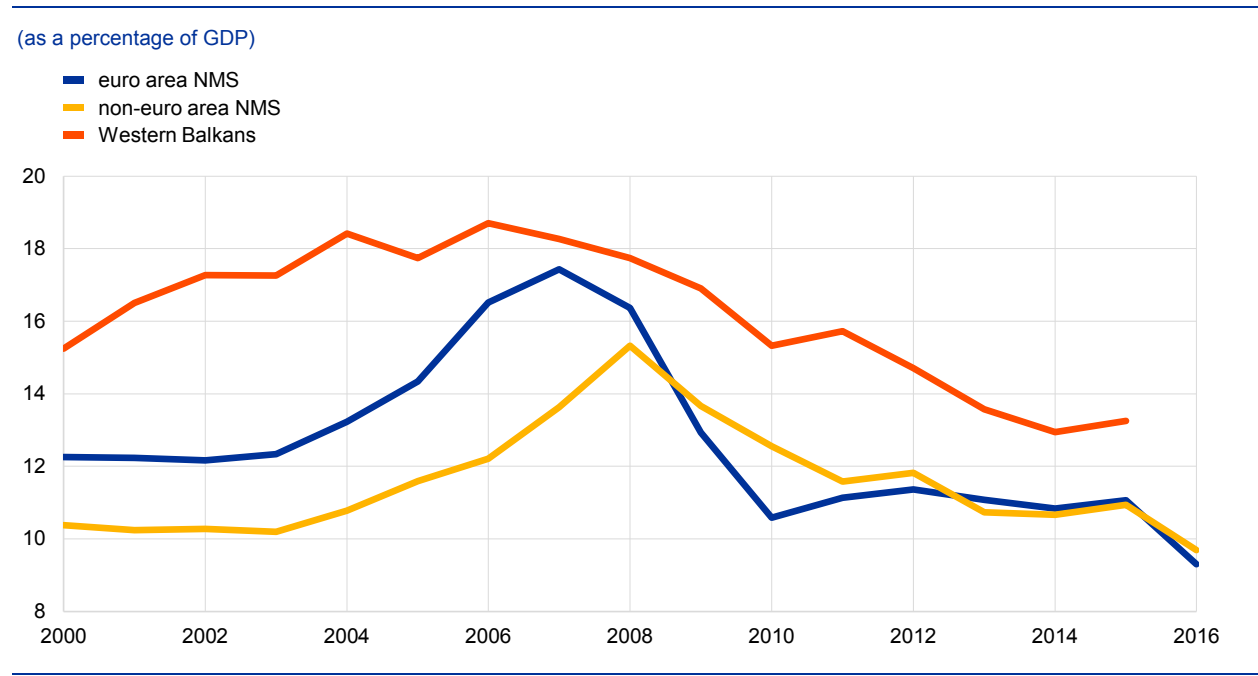

Sources: European Commission (AMECO database) and ECB calculations.

Notes: Averages calculated from all countries for which data are available. In the case of the Western Balkans, these include Albania FYR Macedonia and Serbia. For non-euro area EU Member States, only Croatia has been excluded due to data availability issues.

43 For a more detailed analysis of the role of the EU funds, see the European Investment Fund report entitled "Wind of change: Investment in Central, Eastern and South Eastern Europe", September 2017. 
In general, the larger the saving gaps before the crisis, the larger the downward adjustments in investment rates thereafter. As investment rates fell, they became more closely aligned with domestic saving rates. However, considerable saving gaps persisted in the Western Balkan countries. While capital inflows to converging and capital-scarce economies appear to be essential to foster economic growth and convergence, they might also exacerbate volatility in these economies, in particular if portfolio capital flows or flows to the banking sector predominate over more stable sources of finance such as FDI. Thus, creating a favourable business environment in order to attract FDI is key to providing a sustainable source of investment financing in the longer term.

\subsection{Labour accumulation}

Since $\mathbf{2 0 0 0}$ only some CESEE countries have been able to reap a demographic dividend. While the share of the working age population in the total population increased most in the Western Balkans and in certain new EU Member States (such as Lithuania, Poland and Slovakia), thereby boosting the economic growth potential, it declined in the Baltic countries, the Czech Republic and Slovenia. Against this background, the labour contribution to economic growth in the period 2000-14 was, on average, low in CESEE economies, as compared with other fast-growing emerging economies.

While underlying demographic trends have been heterogeneous overall, all CESEE countries have experienced large emigration flows. In new EU Member States emigration accelerated after these countries joined the EU. The extent of the outflow of the workforce was particularly high in south-eastern Europe - both in countries that have joined the EU and in countries that have not - while it was lower, but still considerable, in central and eastern Europe and in the Baltic countries.

Emigration concerned mostly the young and skilled workforce; this in turn adversely affected productivity and income convergence. ${ }^{44}$

Looking ahead, the challenges related to the falling share of the working age population are expected to increase due to the acceleration in population ageing (see Chart 10). Based on current World Bank projections up to 2030, the share of the working age population in the total population is expected to decline in all CESEE countries. Such developments may have considerable implications for

44 Emigration between 2000 and 2012 reached more than $10 \%$ of the 1990 population in south-eastern European countries, and was half that level in central and eastern Europe and in the Baltic countries; see Atoyan, R., Christiansen, L., Dizioli, A., Ebeke, C., Ilahi, N., Ilyina, A., Mehrez, G., Qu, H., Raei, F. Rhee, A. and Zakharova, D., "Emigration and Its Economic Impact on Eastern Europe", IMF Staff Discussion Note SDN/16/07, 2016. This paper concluded that emigration from CESEE countries contributed to the drain of skilled labour and thus lowered productivity growth and slowed economic convergence to the EU level. 
economic growth. Most importantly, they are likely to have a direct adverse impact on economic potential through lower labour input to production. ${ }^{45}$

\section{Chart 10}

Share of the population aged 15-64 in the total population in 2000, 2016 and 2030

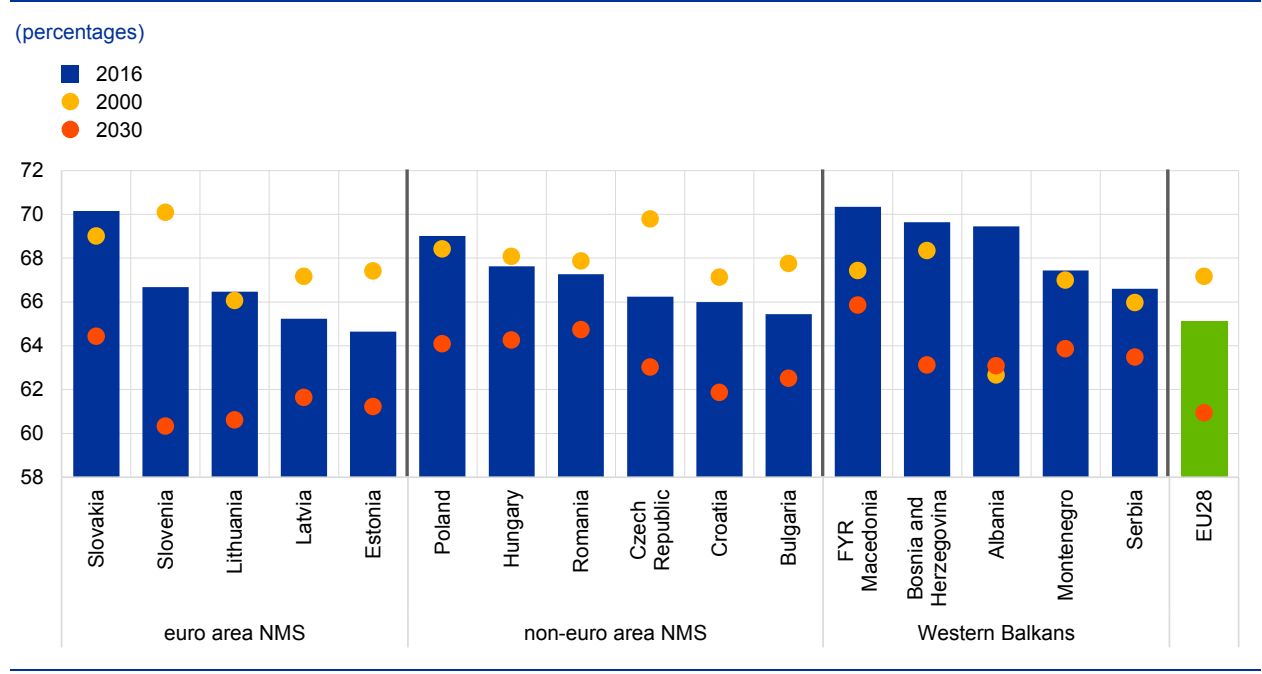

Source: World Bank (WDI).

Note: Data for Serbia include Kosovo.

The potentially negative implications of population ageing and emigration on the labour market could be mitigated by increasing labour market

participation. Although labour market participation rates in the Baltic countries and some central and eastern European countries are already at relatively high levels, there remains significant scope for higher participation in south-eastern Europe, particularly in countries outside the EU. ${ }^{46}$ In these countries, participation rates are, on average, 10 percentage points lower than in the EU28, and in many cases they have declined since 2000 (see Chart 11).

45 At the same time, population ageing may also have indirect effects on economic growth, through its impact on aggregate productivity, saving or the level and structure of public expenditure, although there is still no consensus in the literature on the exact mechanism through which population ageing can affect those variables. It should also be kept in mind that ageing is likely to induce policy and behavioural responses (including the design of pension systems, labour market policies, saving patterns or investment in human or physical capital) that might have an ambiguous impact on economic activity overall.

46 The scope for higher labour market participation is clearly visible when analysing the most vulnerable groups on the labour market, i.e. females and the young and older cohorts. 


\section{Chart 11}

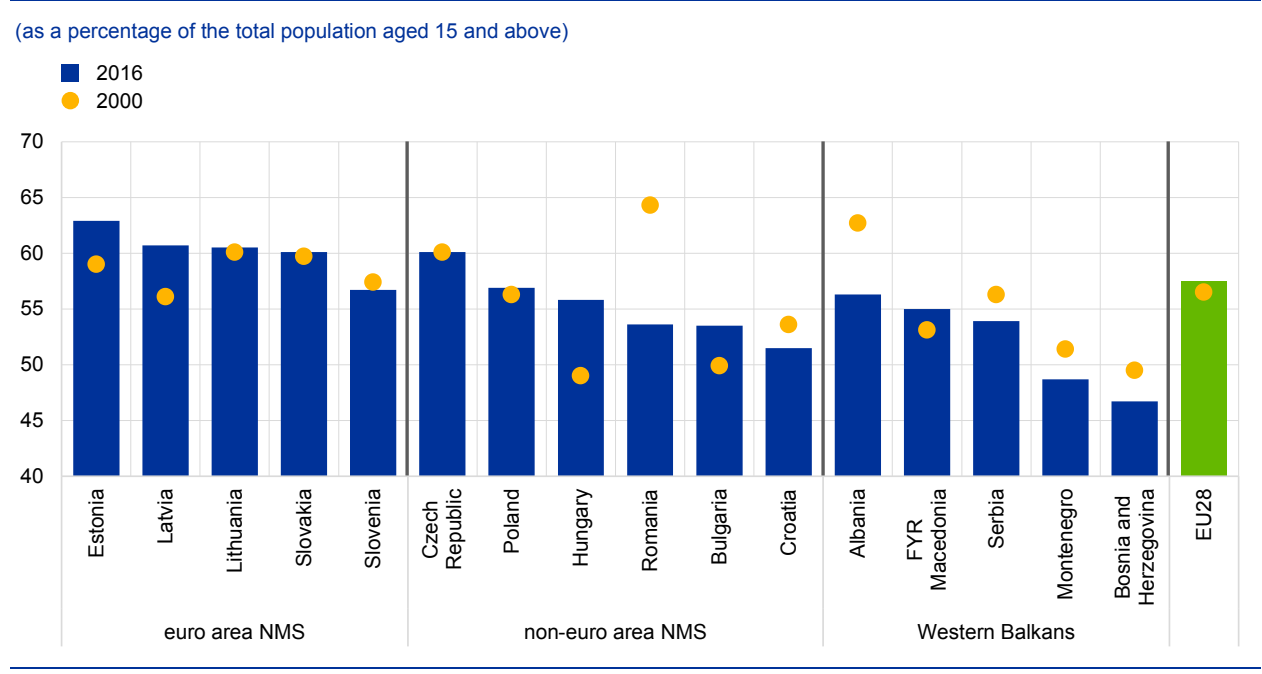

Sources: World Bank (WDI) data compiled by the International Labour Organization. Note: Statistical break in Romania in 2002.

Another potential avenue to mitigate the negative impact of the falling share of the working age population on labour markets is immigration. Notwithstanding large heterogeneity across the countries analysed, in most of them the number of immigrants in relation to the population remains low. ${ }^{47}$ Although in some CESEE economies immigration increased in the period analysed, it was mostly driven by high immigration from other less-developed CESEE countries, which themselves also face future demographic challenges. ${ }^{48}$ Furthermore, attracting immigrants requires offering economic opportunities in the labour market; however these tend to be limited in countries that still suffer from relatively high unemployment, notably the Western Balkans.

\subsection{Drivers of total factor productivity}

This subsection focuses on factors that may have had a tangible impact on total factor productivity in CESEE countries. Total factor productivity measures the efficiency with which labour and capital inputs are used in the production process and is a key driver of sustainable convergence. There are many factors that can influence this efficiency in the production process and this subsection focuses on the impacts of the economic structure, the role of human capital, trade openness and external competitiveness, and innovation. It also considers the fundamental role played by institutional quality, which, as previously indicated, now features more prominently in the convergence literature.

47 The ratio is $3.3 \%$ on average, as compared with $10.6 \%$ in the EU28 (with country averages weighted by population, using United Nations data for 2015).

48 For example, the increase in the number of immigrants in Slovenia since 2000 has been largely driven by inflows of citizens of Bosnia and Herzegovina and the former Yugoslav Republic of Macedonia, while in Hungary it has been driven by inflows of citizens of Romania and Serbia. In recent years, Poland has seen an unprecedented inflow of Ukrainian citizens. 


\subsubsection{Economic structure}

Due to differing productivity levels across economic sectors, the structure of an economy has a direct impact on its aggregate productivity and economic growth. In all CESEE countries the role of services and/or industry in the economy has increased since 2000 , while in parallel the role of agriculture has gradually declined. This has been accompanied by labour reallocation from agriculture to other economic sectors. Such restructuring - typical of catching-up economies - has supported growth, given that productivity in agriculture is usually lower than in other sectors. In some countries, the restructuring was particularly large. For instance, in Albania, the share of employment in agriculture in total employment fell from around $54 \%$ in 2000 to $42 \%$ in 2016 , in Romania it fell from around $45 \%$ to $26 \%$, and in Lithuania, from around $19 \%$ to $9 \%$.

CESEE economies with the highest levels of GDP per capita appear to be more industrialised than other economies at a similar stage of development (see Chart 12). In those more industrialised economies, the relative strength of the industrial sector may be explained by the reallocation of production from western Europe, driven by high FDI inflows, increasing participation in global value chains, lower labour costs and the proximity to more advanced EU economies. At the same time, some CESEE countries are less industrialised than their GDP per capita levels might imply. This is particularly the case for countries in the Western Balkans where agriculture still plays an important role.

\section{Chart 12}

Share of agriculture, industry and services in total value added in 170 economies in 2016

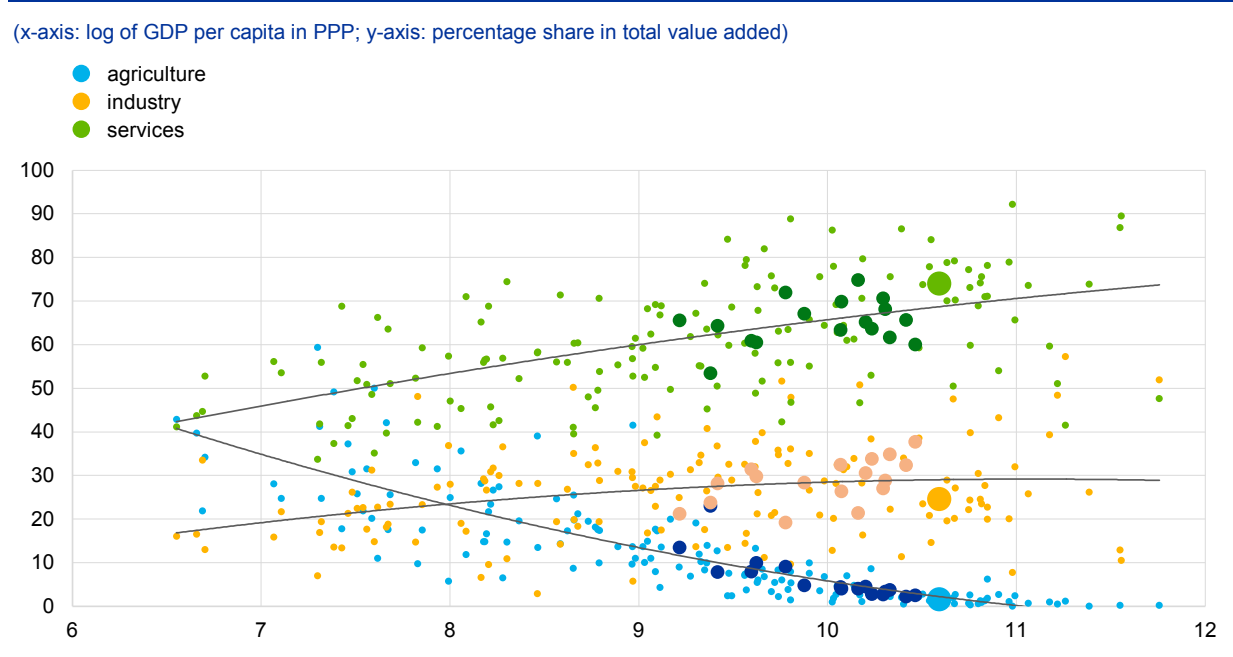

Sources: World Bank (WDI) and Organisation for Economic Co-operation and Development (OECD).

Notes: The darker colours denote CESEE countries and the largest dots, the EU28 average. Data refer to 2015 for 16 countries.

Notwithstanding the positive trends, significant scope remains for further labour reallocation towards services and industry in many CESEE countries. While in some countries the share of employment in agriculture has already reached the low levels typical of advanced economies (this applies particularly to the Czech 
Republic, Estonia and Slovakia), in others it remains high (in particular, Albania and Romania), thus acting as a drag on overall productivity (see Chart 13).

\section{Chart 13}

Labour productivity in industry and agriculture in 2016

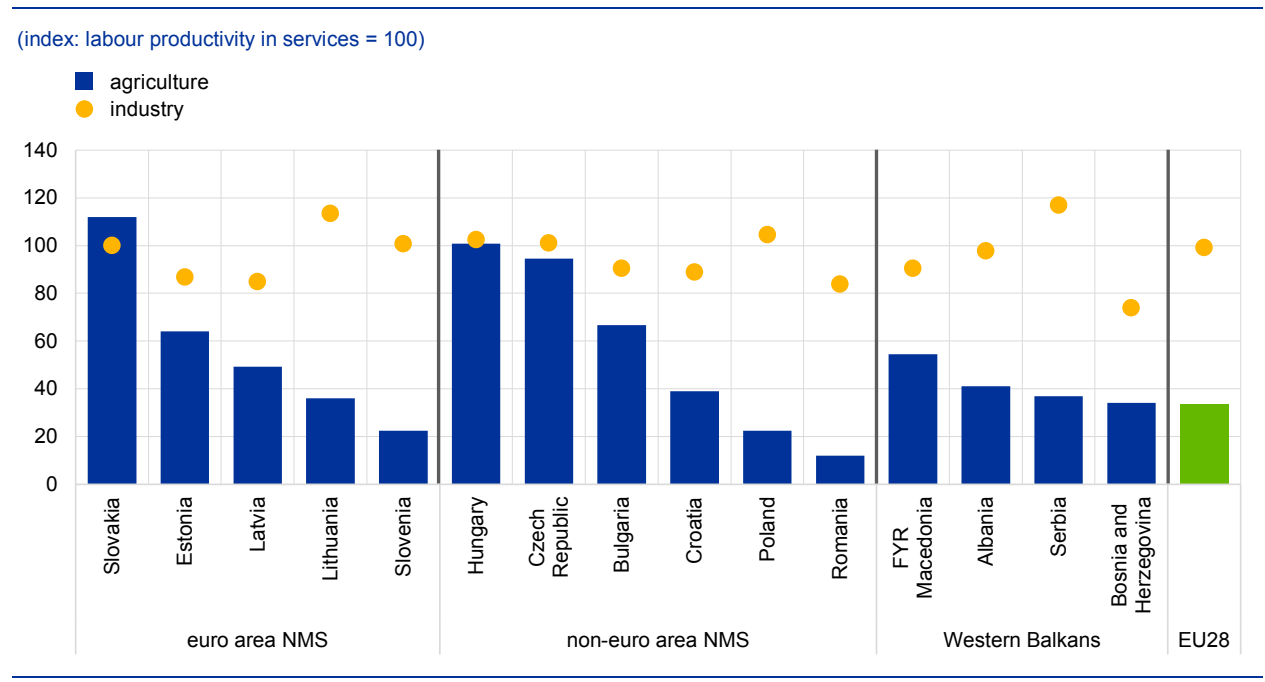

Sources: IMF (World Economic Outlook), World Bank (WDI) and ECB calculations.

Note: Kosovo and Montenegro have been excluded due to data availability issues.

\subsubsection{Human capital}

Human capital levels in CESEE countries appear to be relatively high overall. Although human capital is not directly observable, it can be approximated by variables such as the percentage of the workforce with a higher education or the rates of enrolment in education. On the basis of these metrics most CESEE countries score relatively well compared with the EU average. In particular, the share of the population with at least a bachelor's degree in Lithuania, Latvia and Poland remains higher than the EU average (see Chart 14). At the same time, significant gaps persist in the Western Balkans and in some EU Member States (e.g. Romania), where the share of the population with at least a bachelor's degree remains very low. Enrolment in tertiary education has increased in all CESEE countries since 2000 , pointing to an increase in human capital among younger generations which may give a boost to productivity and economic growth going forward. 


\section{Chart 14}

Share of the population with at least a bachelor's (or equivalent) degree in 2015

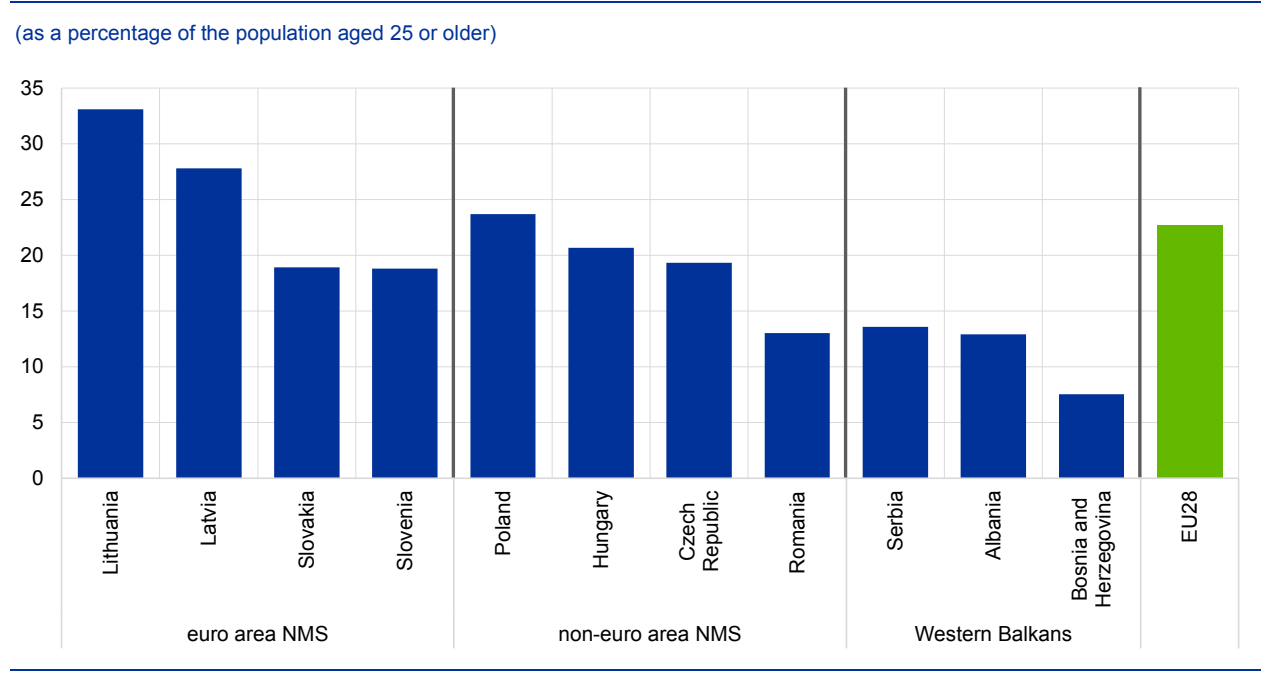

Sources: World Bank (WDI) and ECB calculations.

Notes: Data are not available for all CESEE countries. Data refer to 2014 for Poland and Romania and to 2012 for Albania. The EU average is calculated from all countries for which data are available.

Challenges related to the quality of education and the alignment of skills with labour market needs persist in many CESEE economies. In this context, PISA (Programme for International Student Assessment) scores, showing how 15-year-old students perform in terms of mathematics, reading and science skills, point to a lower quality of education in the Western Balkans and in south-eastern European countries that have already joined the EU (see Chart 15). Conversely, students in the Baltic countries and some central and eastern European countries perform relatively well, pointing to a higher quality of education. At the same time, the alignment of skills with labour market needs remains weak in most CESEE economies; this is contributing to a mismatch in the labour market and to higher unemployment, particularly in the Western Balkans. ${ }^{49}$

49 See also "Central, Eastern, and Southeastern Europe: How to Get Back on the Fast Track", Regional Economic Issues, IMF, May 2016. 


\section{Chart 15}

PISA average score in mathematics, reading and science in 2015 (age 15 years)

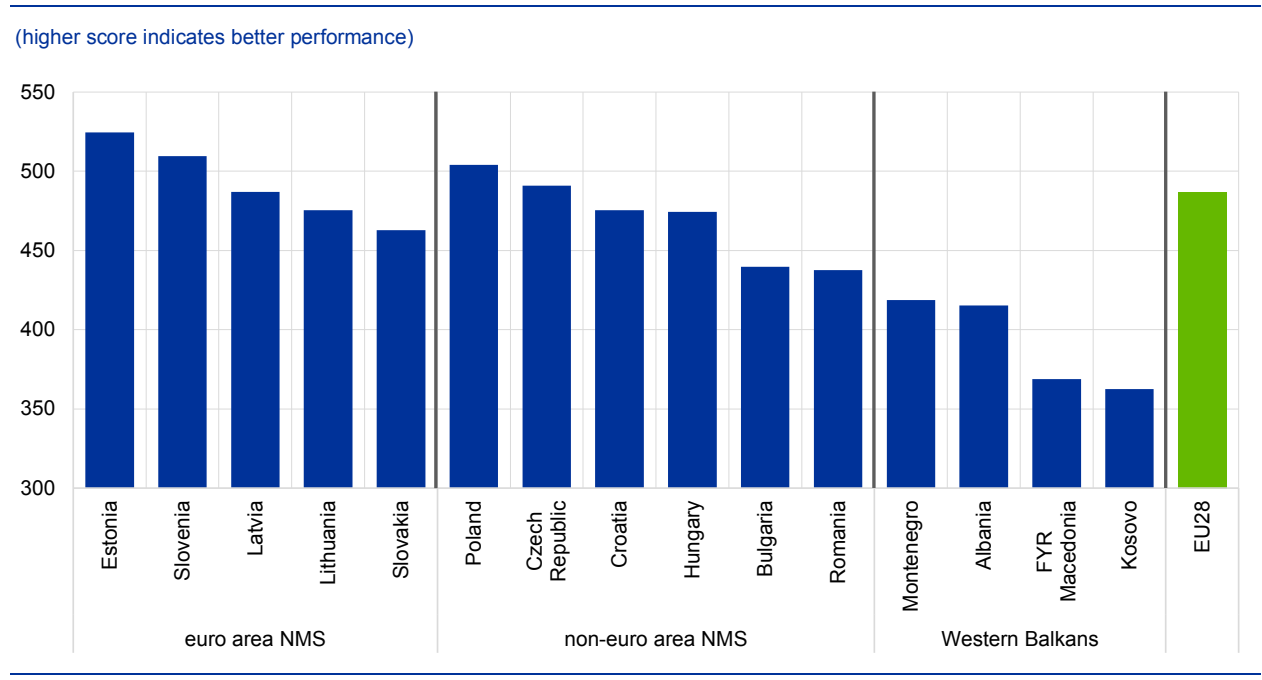

Sources: OECD and ECB calculations.

\subsubsection{Trade openness and external competitiveness}

Trade openness has increased in almost all countries in the CESEE region since 2000, creating favourable conditions for income convergence in these economies. ${ }^{50}$ The most developed or fast-converging CESEE economies (such as the Czech Republic, Estonia, Lithuania, Slovenia and Slovakia) also display high trade openness. However, a high degree of trade openness may not be sufficient to achieve a sustainable convergence process, particularly if it is not accompanied by improving competitiveness.

CESEE countries that have joined the euro area have experienced the fastest growth in trade openness since 2000 (see Chart 16). At the same time, the increase in trade openness in EU Member States outside the euro area was more gradual, which might however also reflect the larger size of those economies. By contrast, trade openness in the Western Balkans has grown only moderately and remains much lower than the EU average. A much faster growth in exports than in imports was a common characteristic in all countries in the region. Against this background, almost all new EU Member States managed to turn trade deficits in 2000 into trade surpluses by 2016. However, in the Western Balkans, notwithstanding that exports have generally grown faster than imports since 2000, large external trade deficits still persist. While significant trade deficits are typical of catching-up economies - which also usually attract capital inflows - large trade

50 Trade openness allows for a reorientation of resources towards more productive sectors. It also encourages innovation and creates opportunities for small economies to access new markets. Increasing trade openness might also pose challenges related to, for example, labour reallocation from import-competing sectors and countries might become trapped in the production of goods and services in which they display comparative advantages, e.g. low-skill and labour-intensive products. For a more extensive review of the challenges related to trade openness, see, for example, Rodriguez, F. and Rodrik, D., "Trade Policy and Economic Growth: A Skeptic's Guide to the Cross-National Evidence", NBER Macroeconomics Annual 2000, Vol. 15, 2001, pp. 261-338. 
imbalances in some Western Balkan countries may also be a sign of a narrow production base and the generally low competitiveness of the countries in the region.

\section{Chart 16}

Trade openness in the period 2000-16

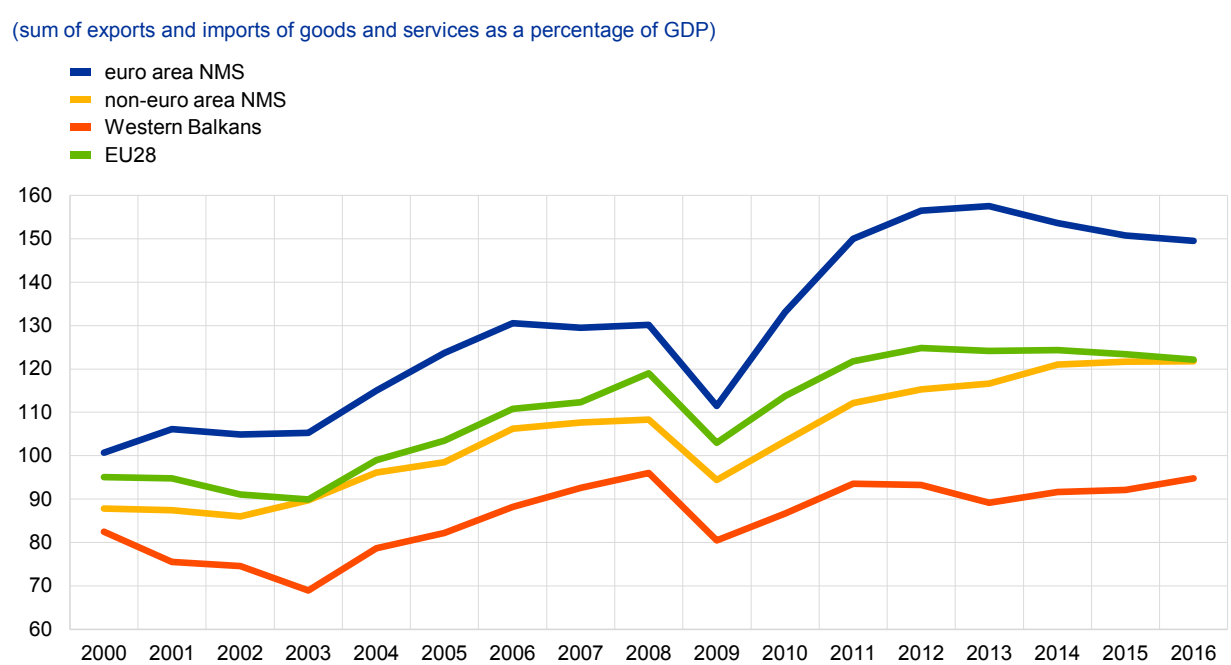

Sources: IMF (World Economic Outlook) and ECB calculations.

Note: Data for Montenegro are available only from 2001 onwards.

Changes in world export market shares - an indication of the ability to compete in global markets - remain heterogeneous in CESEE countries (see Chart 17). Romania, Serbia and the former Yugoslav Republic of Macedonia, on the one hand, managed to significantly increase their share in world merchandise exports, although several of them started from the position of a relatively closed economy with low export levels. The Baltic countries, on the other hand, experienced an impressive boost to exports in the years prior to the global financial crisis in 2008-09, although the increase moderated thereafter. Hungary, which displays one of the highest trade openness ratios, has not been able to increase its share in global exports, suggesting little progress in competitiveness. The main export market of CESEE economies has traditionally been the EU, accounting, on average, for $70 \%$ of merchandise exports. However, export destinations have become more diversified over the past decade and intra-regional trade has increased. 


\section{Chart 17}

Change in world export market shares from 2004 to 2016

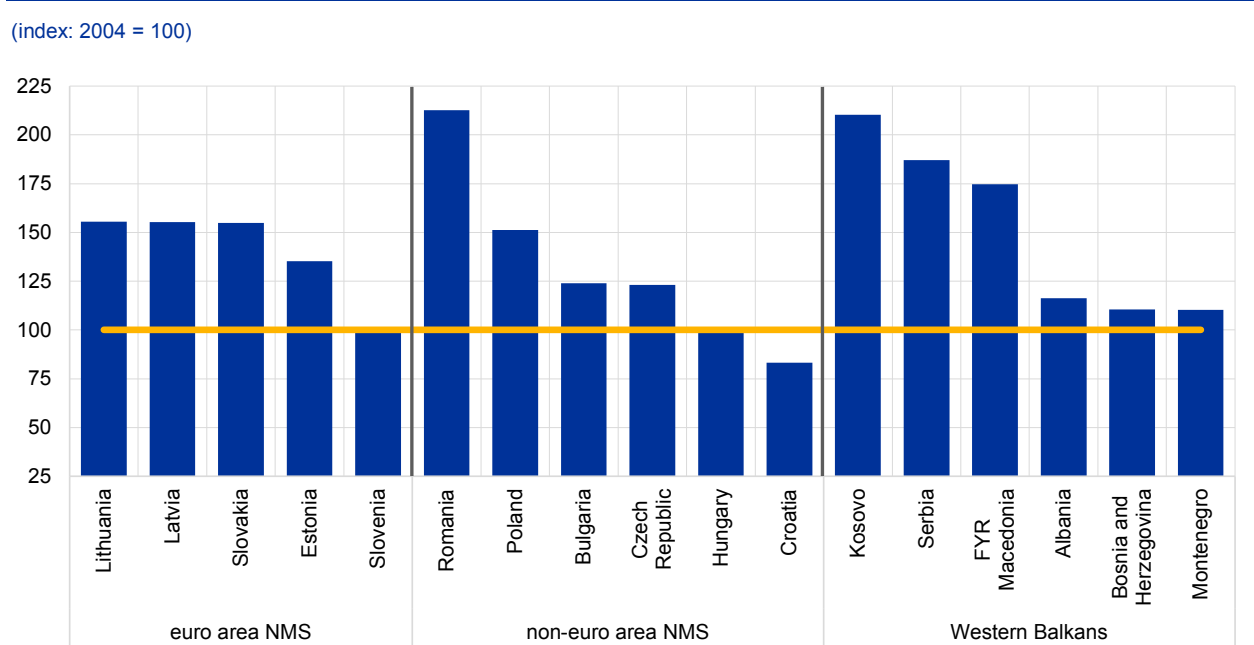

Sources: IMF (World Economic Outlook) and ECB calculations.

Note: The base year is 2004 due to a lack of data for some countries in the sample.

External competitiveness indicators suggest that most CESEE economies score worse than the EU average on many metrics, despite improvements over the past decade (see Chart 18). While marked heterogeneity persists across the individual countries, overall the CESEE region appears to have particular weaknesses in infrastructure quality, business sophistication, and institutions. The performance of the Western Balkan economies is especially weak against all of these metrics. This remains a matter of concern for these countries, in particular where the nominal exchange rate is prevented from properly reflecting domestic developments or helping to restore price competitiveness.

\section{Chart 18}

Global Competitiveness Index 2017-18

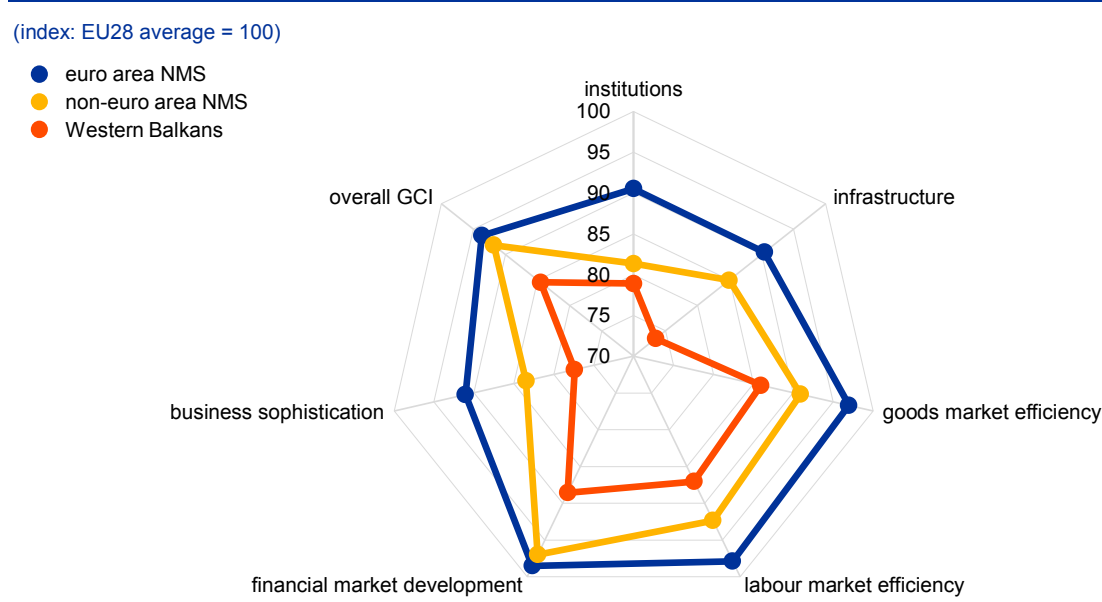

Sources: World Economic Forum (Global Competitiveness Index) and ECB calculations.

Notes: The Global Competitiveness Index (GCl) is calculated on the basis of 12 sub-indicators, of which six are depicted. A higher score indicates a better relative performance. 


\subsubsection{Innovation}

Innovation is a fundamental factor in competing in global markets with higher value-added products and thus successfully converging towards more advanced economies. While low-income countries may be able to converge quickly mainly by accumulating capital and labour and importing technologies and know-how (through capital goods imports or FDI), achieving sustainable convergence may be inhibited by an inability to shift from labour-intensive production to more innovative and more technologically advanced production. Without such a structural shift, countries risk becoming stuck in the "middle-income trap" (see Box 3 ). In the context of CESEE countries - both those that have joined the EU and the current EU candidates and potential candidates - enhancing innovation (and productivity) appears to be fundamental also in the context of European integration and the ability to compete in the Single Market.

While in recent years some CESEE countries have managed to catch up gradually in terms of innovation relative to the EU, others have stalled or even somewhat backtracked. Looking at the number of patent applications per million of population as a proxy for innovation, this indicator has improved notably in the Baltic countries, Poland and Slovenia since 2000. ${ }^{51}$ The heterogeneous development of innovation in CESEE countries suggests that innovation gains are not automatic and may require the pursuit of innovation-supporting policies.

There remains significant scope for improvement in innovation among most CESEE countries, in particular in south-eastern Europe. According to the European Innovation Scoreboard - which classifies economies according to their innovation performance based on a number of metrics - only Slovenia is ranked as a strong innovator, while most CESEE economies are classified as moderate innovators and some - usually those from south-eastern Europe - are classified as only modest innovators (see Chart 19). The strengths of CESEE economies include human resources and an innovation-friendly environment overall (typically in central and eastern Europe and in the Baltic countries). However, these economies lag behind in terms of research quality, small and medium-sized enterprise (SME) innovation (related to products, processes, marketing and organisation), linkages between innovative SMEs and research, linkages between the private and public sectors, and levels of intellectual assets (measured by, for example, patent applications).

51 According to World Intellectual Property Organization data. 


\section{Chart 19}

European Innovation Scoreboard in 2016 for CESEE and other European economies

(as a percentage of the EU28 average)

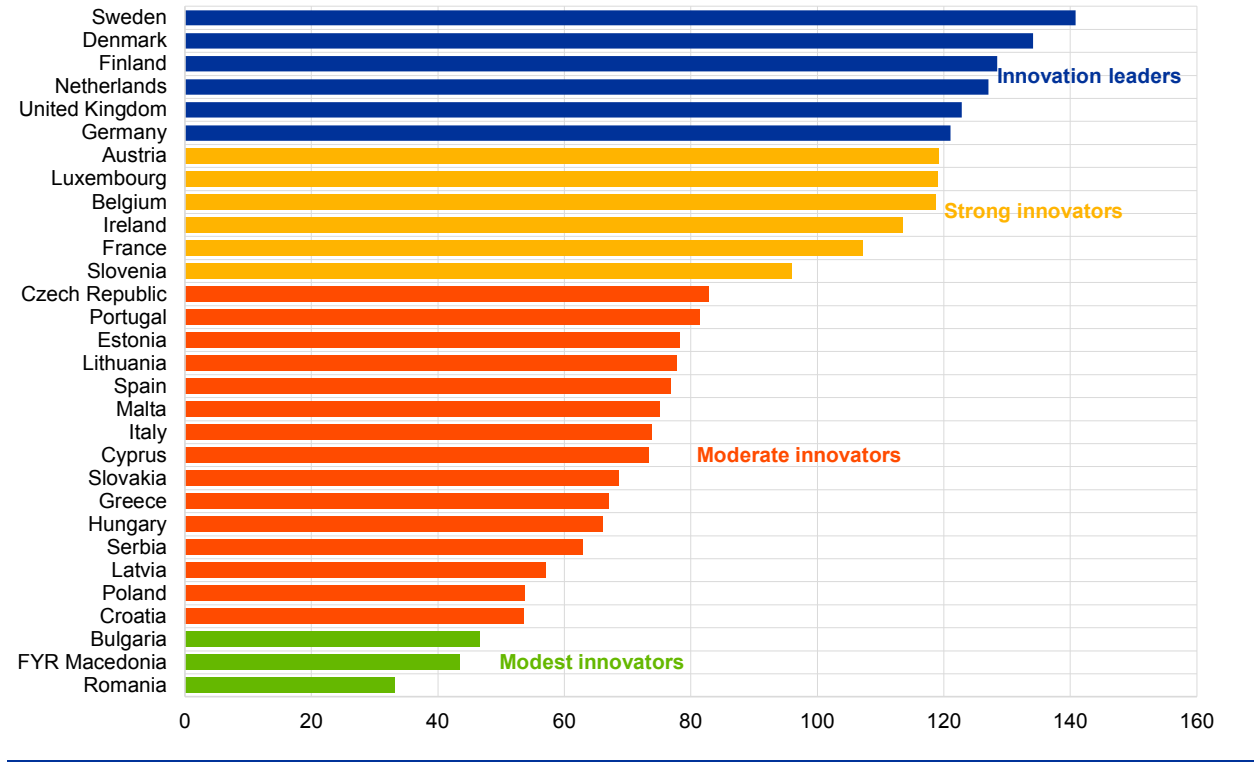

Source: European Commission (European Innovation Scoreboard).

Note: Data are available only for some CESEE economies.

\section{Box 3}

The middle-income trap

Prepared by Piotr Żuk, Eva Katalin Polgar, Li Savelin, Juan Luis Diaz del Hoyo and Paul König

Since the 1960s only a few economies have managed to achieve a sustainable convergence in real GDP per capita from low/middle income to high income (these include Hong Kong, Ireland, Japan, South Korea, Singapore and Taiwan). Many low-income countries managed to reach middle-income status, but failed to continue to converge to high-income status thereafter, thus inspiring a discussion on the so-called "middle-income trap". According to the hypothesis, after reaching middle-income status economies follow a lower growth trajectory, which prevents them from achieving higher income levels. This slowdown in economic growth is often associated with, inter alia, unfavourable demographics and a fall in investment rates from previously high levels - the latter suggesting an over-reliance of GDP growth on capital accumulation at the early stage of catching-up. The slowdown is less likely in middle-income economies with higher levels of human capital and where high-technology products account for a relatively large share of exports. ${ }^{52}$

The middle-income trap is usually explained by the observation that the initial advantages of a catching-up economy may disappear once a certain level of development has been reached. In particular, at an early stage of development low-income countries may achieve high GDP growth relatively easily due to low labour costs (therefore being highly competitive in global markets when

52 The slowdown typically happens after the countries reach USD 10,000-11,000 and USD 15,000-16,000 GDP per capita in 2005 PPP dollars. See Eichengreen, B., Park, D. and Shin, K., "When Fast Growing Economies Slow Down: International Evidence and Implications for China", NBER Working Paper No 16919, 2011, and Eichengreen, B., Park, D. and Shin, K., "Growth Slowdowns Redux: New Evidence on the Middle-Income Trap", NBER Working Paper No 18673, 2013. 
producing labour-intensive goods), to labour reallocation from lower to higher productivity sectors (e.g. from agriculture to manufacturing) and to the import of advanced technologies. However, once wages increase to international levels (thereby hampering external competitiveness) and the sectoral reallocation of labour has been largely completed, further productivity and economic growth gains require a shift from labour-intensive production towards more innovative and technologically advanced production. As this shift remains challenging once a country reaches middle-income levels, many countries fail to converge further..$^{53}$

Analysis of a large set of countries over a longer time perspective shows that evidence supporting the middle-income trap hypothesis is, however, mixed (see the chart). Although only a small number of the middle-income countries have managed to join the high-income group since 1960, many of them have been able to narrow their distance from the most developed economies.

\section{Chart A}

GDP per capita in 1960 and 2016 in 147 economies

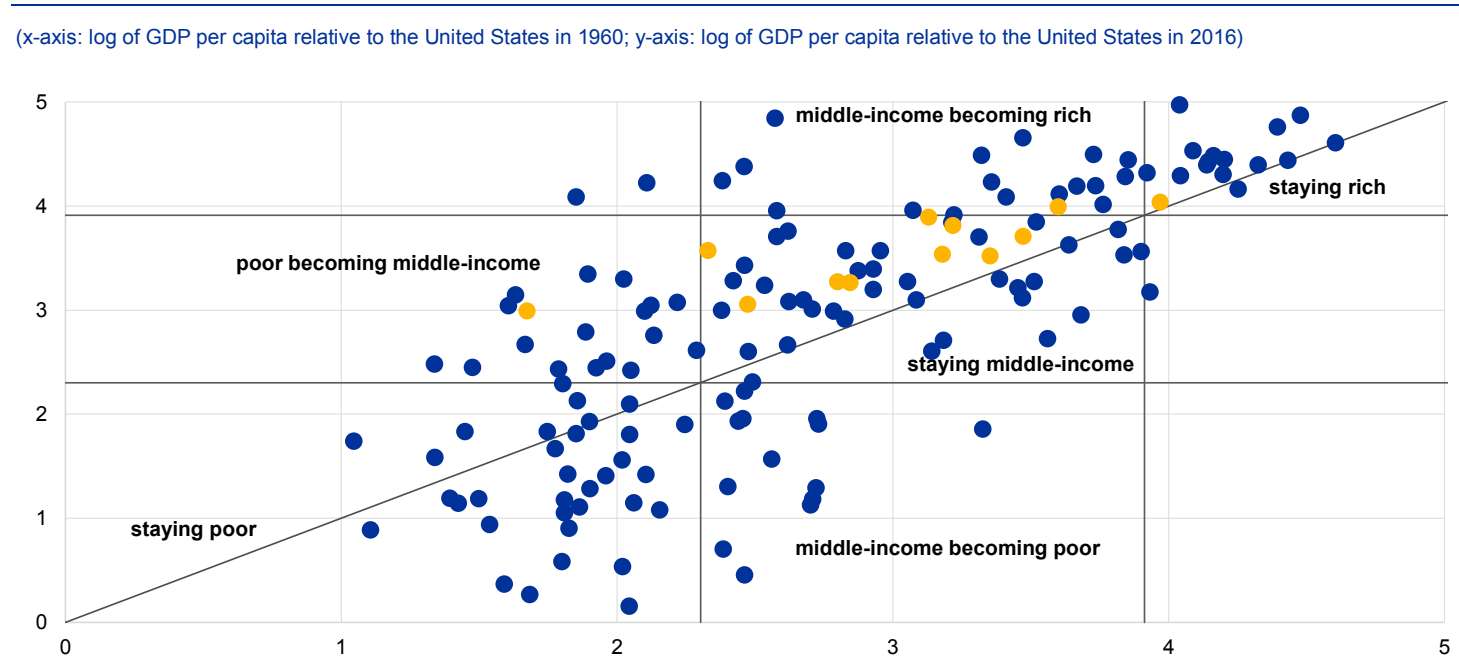

Sources: Maddison Project Database (2018 version) and Bolt, J., Inklaar, R., de Jong, H. and van Zanden, J.L., “Rebasing 'Maddison': new income comparisons and the shape of long-run economic development", Groningen Growth and Development Centre Research Memorandum, Vol. GD-174, 2018. Notes: "Middle income" is defined arbitrarily as the income between $10 \%$ and $50 \%$ of the US GDP per capita. The yellow dots represent CESEE economies for which data are available. A similar chart can be found in Agénor, P.R., Canuto, O. and Jelenic, M., "Avoiding Middle-Income Growth Traps", Economic Premise Number 98, World Bank, 2012.

Since 2000 some of the CESEE countries (for example Lithuania, Poland and Romania) have experienced particularly fast convergence and there are no apparent signs of a slowdown in the pace of the catching-up process. At the same time, other CESEE EU Member States have found it difficult to converge to the EU28 average beyond the levels already achieved up to 2008. Given these heterogeneous developments, it appears that while for some CESEE countries the middleincome trap hypothesis can be dismissed (at least given their experience so far), in others the signs of a slowdown in convergence after reaching a certain level of income are visible. ${ }^{54}$

53 See for example Agénor, P.R., Canuto, O. and Jelenic, M., "Avoiding Middle-Income Growth Traps", Economic Premise Number 98, World Bank, 2012.

54 It should be emphasised that a slowdown may take place at different levels of development. For example, some CESEE countries which experienced a slowdown in convergence are already classified as high-income countries (according to the World Bank classification). However, the factors which might be holding back further convergence might be similar to those for countries classified as middle income, and thresholds for income classifications are to some extent arbitrary. 


\subsubsection{Institutional quality}

The quality of institutions is seen as a fundamental explanation of economic growth and of differences in economic development across countries in the long run. ${ }^{55}$ Accordingly, among CESEE countries one can also observe a strong correlation between the quality of institutions and the level of GDP per capita. Although institutions are endogenous, meaning that they are determined by a society and may be a function of its income, their improvement does not necessarily occur automatically as economic development progresses.

Changes in institutional quality in the CESEE region in recent decades need to be analysed in the context of the transition of these countries from command economies to market economies. While the transition in new EU Member States was rather rapid and took place mostly at the beginning of the 1990s, the pace of the transition in the Western Balkans was much slower. This was largely due to the "lost decade" after the Yugoslav wars, which led to a delay in the implementation of reforms. Thus, most Western Balkan economies only achieved a relatively advanced degree of transition in the areas of privatisation and price liberalisation in the early or mid-2000s, according to the EBRD transition indicators. However, in several domains (in particular competition policy and corporate governance) further market reforms are still required.

Along with the transition to a market economy, institutions in CESEE countries became more supportive of growth. In recent decades, most CESEE economies have managed to improve considerably in areas such as control of corruption, rule of law, government effectiveness and regulatory quality. The fastest improvement took place in some of the Western Balkan economies, although from very low levels, as well as in the countries that had already joined the euro area.

However, in most CESEE countries there remains a significant difference in institutional quality compared with the average level observed in the EU. In particular this concerns the Western Balkans, where institutional quality remains particularly low due to (inter alia) higher corruption, weaker rule of law and lower regulatory quality, while the business environment is to a large extent hampered by weaknesses in enforcing contracts, resolving insolvency and registering property. Furthermore, it is also noteworthy that the improvements seen in governance indicators in non-euro area new EU Member States since the mid-1990s seem to have stalled in recent years, in clear contrast to the situation of the CESEE countries that joined the euro area (see Chart 20).

55 On the role of institutions in convergence and economic growth, see Box 2 of this article, entitled "Theories of convergence and economic growth". 


\section{Chart 20}

Worldwide Governance Indicators (delivery index)

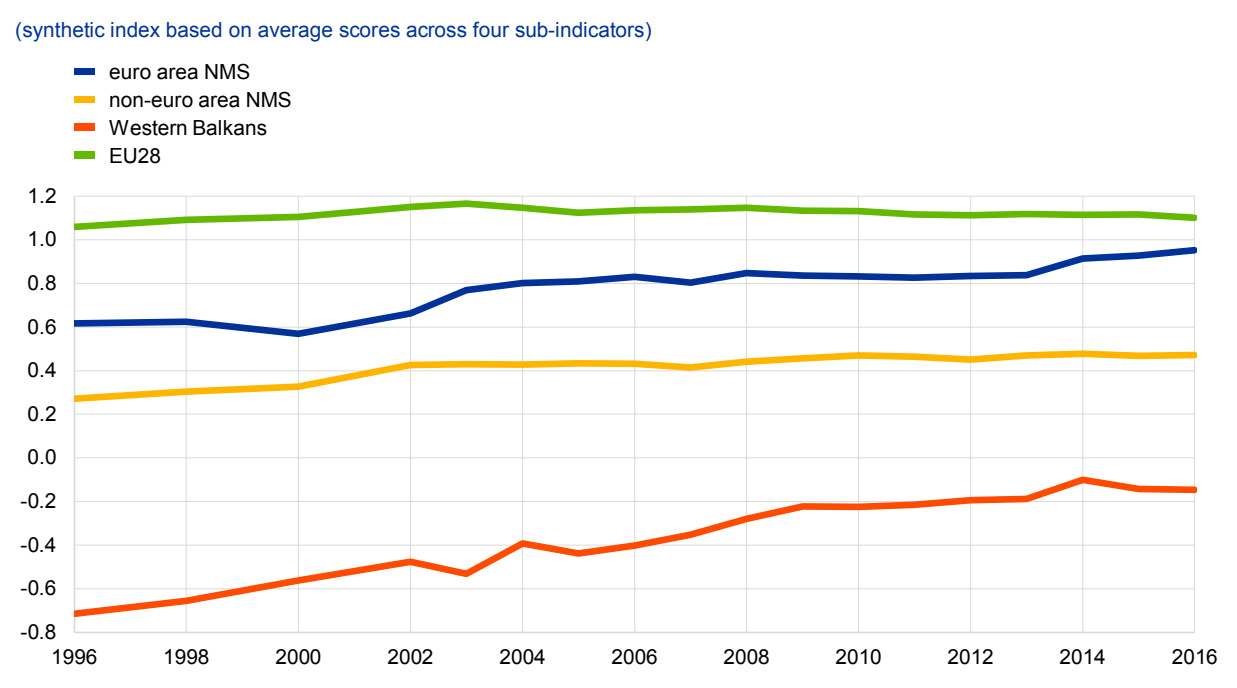

Sources: World Bank (Worldwide Governance Indicators - WGI) and ECB calculations.

Notes: The WGI delivery index is a simple average of the sub-indicators regulatory quality, government effectiveness, control of corruption and rule of law. A higher index implies a better relative performance in institutional quality.

EU accession constitutes an important anchor for institutional reforms. As can be seen in Chart 21, in new EU Member States the most significant efforts to improve institutional quality took place in the years prior to EU accession, while progress since then has been limited in many of them, in particular in the countries that remained outside the euro area. For this latter group of countries, efforts aimed at strengthening institutional quality would be conducive not only to accelerating real convergence, but also to abiding by the economic criteria for Monetary Union membership laid down in the Treaty. These criteria include price stability and fiscal policy soundness, which support long-term growth and macroeconomic stability and enhance resilience to economic shocks. 


\section{Chart 21}

Average annual change in the Worldwide Governance Indicators (delivery index) in new EU Member States relative to the year of EU accession

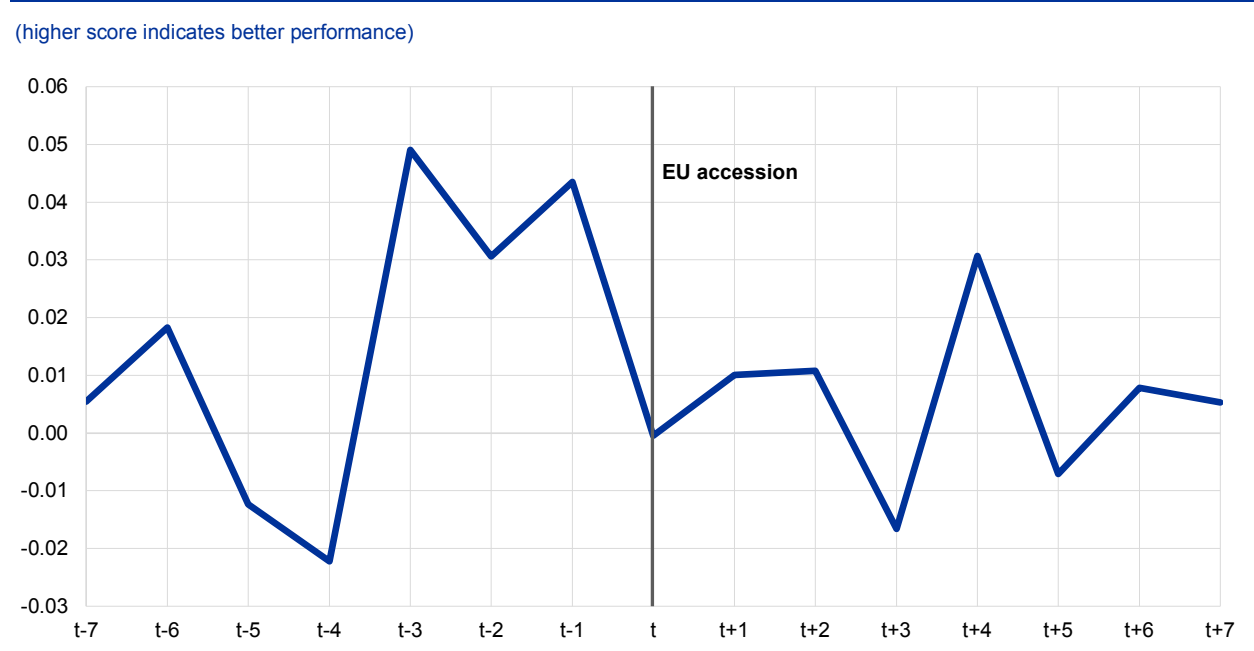

Sources: World Bank (Worldwide Governance Indicators - WGI) and ECB calculations.

Notes: The WGI delivery index is a simple average of the sub-indicators regulatory quality, government effectiveness, control of corruption and rule of law.

On average, the CESEE countries that have joined the euro area have also maintained the positive reform momentum in recent years. As a result, institutional quality in these countries has converged close to the EU average. This is a positive development, given the more favourable growth prospects associated with a better quality of institutions and the fact that strong institutions remain crucial to ensuring the sustainability of convergence.

Similarly, the quality of institutions also remains a fundamental factor for the EU accession process in the Western Balkans. Further strengthening the institutional quality in these countries remains essential not only for creating favourable conditions for economic growth, but also for complying with the Copenhagen criteria for EU accession. These criteria include the stability of institutions guaranteeing democracy and the rule of law, the existence of a functioning market economy and the capacity to cope with competitive pressure and market forces within the EU. In turn, EU accession prospects might create an anchor for the reform momentum in these countries conducive to enhancing institutional quality, as was the case for countries in the region that have already joined the EU.

\section{Conclusions}

CESEE economies have managed to narrow their gaps to the EU average in terms of GDP per capita in the period analysed in this article (i.e. since 2000). This has obvious positive welfare implications for these countries and constitutes a positive development in the context of economic and monetary integration with, and within, the EU. However, the pace of convergence has been heterogeneous across countries. 
Most CESEE countries that have joined the EU have been converging relatively quickly and a few of them have already reached GDP per capita levels that are close to the EU28 average. In this respect, EU accession has been an important anchor in the convergence process, particularly in the pre-accession years. The fastest pace of convergence has been observed in some of the countries that have joined the euro area (in particular the Baltic countries and Slovakia), as well as in some non-euro area EU Member States, such as Poland. The pace of convergence of those Western Balkan economies which have a prospect of joining the EU has been, on average, slower, and their distance to EU economies in terms of income levels remains substantial. In most CESEE countries the catching-up was more dynamic before the 2008-09 global financial crisis; after the crisis, convergence to the EU level slowed in most countries amid weaker TFP growth and capital accumulation.

The most successful CESEE economies in terms of the pace of convergence share certain common characteristics. First, most of them considerably improved institutional quality. Second, they increased external competitiveness amid rising trade openness and innovation. Third, most of them experienced relatively favourable demographic developments, or significantly increased their labour market participation rates. The fastest-converging economies also exhibited very significant improvements in human capital levels, or their levels of human capital were already among the highest in the region. Investment rates also tended to be higher, as compared with peers.

Looking ahead, CESEE countries face several challenges in the convergence process. These include further improving institutional quality, reorienting their economies towards more innovative production, reinvigorating investment and ensuring its sustainability, and addressing the adverse impact of population ageing. While some of these challenges are more difficult to address through dedicated policies than others, domestic policymakers should pay attention to them in an endeavour to continue, and possibly accelerate, the process of catching up with the EU. 